\title{
Mentor and Protégé: Percy Ellwood Corbett's Relationship with John Peters Humphrey
}

\author{
A.J. HOBBINS
}

$\mathrm{T}$ HE FACULTY OF LAW AT McGill University has a remarkable history in terms of its curriculum. Although the faculty has always offered civil law programs, it also offers its graduates the opportunity of receiving a common law degree. The National Program, which was inaugurated in 1968, offered students the option of receiving both degrees for an additional year's study, while the

A.J. Hobbins, Associate Director of Libraries, McGill University, and literary executor to the estate of John Humphrey. I would like to thank a number of people who have helped in the preparation of this article. Professor Desmond Morton, Director of the McGill Institute for the Study of Canada and renowned military historian, helped me with some aspects of Corbett's military career as a member of the Canadian Expeditionary Force. Robert Clarke, Law Librarian at McGill University and former officer of the Black Watch (Royal Highland Regiment) of Canada, provided some specific details of Corbett's war service from the Regimental Archives. Kathleen Fisher, who is preparing an intellectual biography of Corbett, gave me some useful personal glimpses, including the story behind the last meeting of Corbett and Humphrey. Gordon Burr and Johanne Pelletier of the McGill University Archives were most helpful in providing access to the Corbett and Humphrey papers in their care. Daniel Boyer, Wainwright Librarian at McGill's Nahum Gelber Law Library, tracked down for me a number of published, but sometimes quite obscure, items. The Document Delivery staff at McGill University and other institutions provided important materials not available locally. Professors J.E.C. Brierley and R.A. Macdonald of McGill University, and Professor Mary Ann Glendon, Learned Hand Professor of Law at Harvard University, were all kind enough to comment on earlier versions of this manuscript, thus strengthening its content. I must mention my friend, Professor Warren Dicks of the Universitat Autònoma de Barcelona, whose ability to spot tautologies, malapropisms, and other infelicities of language is matched only by my ability to create them. My deepest debt of gratitude is to Ronald St. John Macdonald, who first suggested to me that Humphrey's tribute to Corbett should have been published nearly ten years ago and who has since encouraged my scholarly endeavours. He too provided valuable commentary on the manuscript. 
current regime makes the two degrees mandatory and obtainable within three years. In addition to teaching both branches of the law, the McGill Faculty of Law also holds a remarkable tradition in international law. Indeed, in its early days, "McGill, among all Canada's law schools, was not only the school which virtually alone offered a programme in international legal studies but, more importantly, did so with strength and distinction." In the twentieth century, one's attention is certainly drawn to John Peters Humphrey (1905-95), who taught in the faculty for forty years, bracketing his service of two decades at the United Nations during which he authored the first draft of the Universal Declaration of Human Rights. Another outstanding example is Maxwell Cohen $(1910-98)$ who, as dean, initiated the National Programme and later became a judge on the Ad Hoc International Court of Justice. ${ }^{2}$ Cohen "became an international lawyer by accident - when McGill invited [him] to teach the course in 1946" as Humphrey's successor. ${ }^{3}$ John Cobb Cooper (1882-1967) added a new dimension through the creation of what has now become the Institute of Air and Space Law in 1951. The tradition in international law continues to this day through the internationally renowned teaching and research done in air and space law, maritime law, the international law of human rights, and the discipline of medicine, ethics, and law. While the McGill faculty's commitment to international law began in the nineteenth century, ${ }^{4}$ it might have faded away when Ira Mackay, who was supposedly despairing for the future of the scholar-lawyer within the Faculty of Law, moved to the Faculty of Arts in $1924 \cdot{ }^{5}$ Mackay, however, was succeeded by perhaps the

1 R. St. J. Macdonald, "An Historical Introduction to the Teaching of International Law in Canada" (1974) 12 C.Y.I.L. 67 at 81. Praise from Judge Macdonald, one of Canada's most distinguished international lawyers and a former dean of law at Dalhousie University and the University of Toronto, must inevitably be taken seriously and be a source of pride.

2 R. St. J. Macdonald, "Maxwell Cohen at Eighty: International Lawyer, Educator and Judge" (1989) 27 C.Y.I.L. 3, provides an excellent summary of Cohen's achievements in the field of international law.

${ }^{3}$ Macdonald, supra note 1 at 78.

${ }^{4}$ Starting in 1856 during the Faculty of Law's first decade, Frederick W. Torrance offered one hour per week in international law. Macdonald, supra note 1 at 69 .

5 R.A. Macdonald, "The National Law Programme at McGill: Origins, Establishment, Prospects" (1990) 13 Dalhousie L.J. 259. While this substantial article concentrates on the National Law Programme, which began in 1968, it also serves as a useful history of the faculty from its inception over a century before. Elsewhere, Mackay stated that for a "first class law school ... two things are 
most important individual in McGill's long tradition. That individual was Percy Ellwood Corbett (1892-1983), who not only taught

necessary, viz: legal research and uniform legal education, based upon the results of research." Stanley Frost and David L. Johnston, "Law at McGill: Past, Present and Future" (1981) 27 McGill L.J. 36. Frost and Johnston suggest that had Mackay remained "he would have been a major liberalizing influence in the faculty." It is probable that they meant a liberalizing influence in terms of the scope of the curriculum (law as liberal education versus law as professional training), for if they used "liberal" in a more general sense their assertion could be challenged on two grounds. First, following Mackay's resignation the faculty appointed Corbett and, within four years, F.R. Scott, who were surely liberal enough influences in their own right. Second, there is a significant body of evidence that indicates Mackay was less than liberal in some areas and was in fact strongly anti-Semitic. David Lewis, later a Rhodes scholar, tells of questioning Mackay over a failing grade and being berated for his backward race (Lewis seemed unsure whether this was because he was Polish or Jewish). David Lewis, The Good Fight: Political Memoirs 19og1958 (Toronto: Macmillan, 1981) at 23-24. Lewis's experience accurately reflected the shameful views Mackay himself formalized on April 23, 1926, when he wrote a five-page letter on the "Jewish problem" to Principal Currie. Mackay started by stating that Jews were the least desirable immigrants to Canada, continued through the stereotypical view that Jews all became professionals, "money lenders and middle men" of which Canada already had too many, and concluded with a plan for reducing Jewish enrollment by establishing quotas and subjecting Jews to far more rigorous admission standards. McGill University Archives, "Jewish Students at McGill," RG2, Cont. 46, File 445 . The Faculty of Law had the highest Jewish enrollment (4o per cent) at the university in 1924. After an even more stringent version of Mackay's plan was regrettably adopted, Jewish enrollment in law, still the highest in the university, fell to 15 per cent by 1939 . These restrictions were not eased until after the Second World War. Seven years after this letter, in response to the Royal Society of London's appeal to place German refugee scholars in western universities, Mackay again offered his advice to Principal Currie, writing on July 21 , 1933: "The simple obvious truth is that the Jewish people are of no use to us in this country. Almost all of them adopt one of the four following occupations, namely, merchandising, money lending, medicine and law, and we have already far too many of our own people engaged in these occupations and professions at present. This is not a case of anti-Semitism at all. I have the highest regard for the better class of Jews, some of whom are our best citizens, but as a race of men their traditions and practices do not fit in with a high civilization in a very new country." McGill University Archives, "Jews - Protestants, Education and Germany," RG2, Cont. 46, File 443. The "better class of Jew" appears to be those whose ancestors had come to Canada in the previous century as opposed to the new wave of immigrants. These documents, previously published in several places, were drawn to my attention by Paul Axelrod's interesting article, "McGill University on the Landscape of Higher Education: Historical Reflections" (1998) 10 Fontanus 17 at 28 . The most charitable way to assess Mackay's views is to assume they merely mirrored the general anti-Semitism endemic in society at that time. Nonetheless, given those views and the size of the Jewish population in law, the faculty was perhaps fortunate that Mackay took his liberalizing influence to the Frothingham Chair of Logic and Metaphysics. 
international law as an adjunct to the undergraduate program but also made it the legitimate subject of scholarly research. ${ }^{6}$ Corbett was an outstanding scholar who made the careers of his protégés possible and yet, despite his notable achievements, he was a man who has received relatively little recognition. ${ }^{7}$

\section{Peripatetic Childhood}

Percy Corbett was born in Tyne Valley, Prince Edward Island the fifth of eight children. His father, Thomas C. Corbett, was a Presbyterian minister who seemed unable to stay in any parish for very long. Apart from a few scattered incidents, Corbett's earliest memories were of Blackville, New Brunswick, by which time his father had left not only Prince Edward Island but also parishes in South Framingham, Massachusetts, St. Andrews, New Brunswick, and Kirkland, New Brunswick. In his own words: "My memories of the family as an undivided group date from Blackville, New Brunswick, which we reached in $1898 .{ }^{.8}$ In his early years, his care was largely entrusted to his three older brothers, who were wont to drag him around the countryside in a battered old wicker baby carriage. ${ }^{9}$ On occasion, they would send the carriage careening down hills with the terrified toddler holding on grimly to the sides. An older brother felt that this treatment had no serious side effects, stating: "Since my brother has turned out to be the most distinguished member of the family, it is perhaps reasonable to suggest that his physical and intellectual vigour, as well as his powers of endurance, derived partly from the spartan training we gave him in his youth." 10 When the family moved to Rockburn, Québec, for a stay of five years, Corbett was at an age when

${ }^{6}$ Interestingly, before Corbett's appointment, Mackay taught international law, but it was H.A. Smith, professor of jurisprudence and common law, who wrote most of the scholarship in international law emanating from the faculty.

7 Macdonald, supra note 1 at 75, termed Corbett "one of the most original and creative international lawyers that Canada has ever produced," but notes he only received recognition in Canada when awarded the Judge Read medal in 1972.

${ }^{8}$ Late in life, Corbett prepared a brief handwritten autobiography on which he put the covering note: "This spotty record is intended for Corbetts only." Various versions of the text survive in the McGill University Archives, "Handwritten Record of P.E.C. Life," MG 4195 , Cont. 002, File 6. Each chapter is separately titled and paging is not uniform. This quotation is from "The Family" at 5 .

9 E.A Corbett, Father, God Bless Him (Toronto: Ryerson Press, 1953) at 1 2-33.

10 Ibid. at $15^{-16}$. 
education was becoming important. He still attended a small rural school, but his father began to take a direct hand in his education: "In Rockburn ... Father began teaching me Latin and history in his study. This was something the rural school could not give me, and I owed it to him that I was able to skip two preparatory years and enter Huntingdon Academy better equipped than most of my fellow students." (after two further years in Huntingdon) moved on to Elm Creek, Manitoba. Upon graduation, he entered the Faculty of Arts at McGill University. He did remarkably well academically, given the unusual nature of his previous schooling, obtaining not only a first-class honours degree in English and Latin in 1913, but also the award of one of Canada's early Rhodes scholarships. ${ }^{12}$

\section{CORBETT AND THE First WORLd WAR}

Corbett did not take up his Rhodes scholarship in 1914 . He attempted to enlist in the Canadian army but failed the eyesight test. He stayed at McGill to complete his Master of Arts while serving in the McGill University contingent of the Canadian Officers' Training Corps (COTC), which had been formed in $1912 .{ }^{13}$ On completion of his degree, he visited a more understanding optometrist and was able to be commissioned with the Royal Highlanders of Canada (RHC) in September 1915 , serving with the $73^{\text {rd }}$ Battalion until 1916 and then the $13^{\text {th }}$ Battalion as part of the Canadian Expeditionary Force.${ }^{14}$ For a brief period, Corbett kept a diary in the trenches, which showed his own sense of wonder at being spared while others fell and which provides some unusual glimpses of life at the front not often found in official

11 Corbett, supra note 8, "The Family" at 3

12 Rhodes scholarships were first awarded in 1903 and, in Canada, in 1904. Canada received approximately one scholarship per province, averaging eight per year in the initial phases. See George R. Parkin, The Rhodes Scholarship (Toronto: Copp Clark, 1912).

${ }^{13}$ R.C. Fetherstonhaugh, McGill University at War, I914-1918, 1939-1945 (Montreal: McGill University, 1947) at 2.

14 Professor Desmond Morton (see first unnumbered note), in commenting on an earlier draft of this article, pointed out that the $73^{\text {rd }}$ Battalion "narrowly missed being broken up in England but was saved by the political influence of its officers and joined the $12^{\text {th }}$ Brigade of the $4^{\text {th }}$ Division. In the process, it gave up several drafts or trained soldiers, and presumably Corbett was among them." Corbett, supra note 8, "The First World War and I" at 2, states: "It was always a nasty satisfaction to me that I got to France months before the $73^{\text {rd." }}$ 
histories.$^{15}$ He received a slight wound in 1916 but missed very little active duty. The $13^{\text {th }}$ Battalion, as part of the $1^{\text {st }}$ Division under Major-General Sir Arthur Currie, returned to the front lines for the Battle of Arras in the spring of 1917. This battle began with the famous and successful attack on Vimy Ridge, after which the $13^{\text {th }}$ RHC continued trench warfare activity over the next three months around the villages of Arleux and Fresnoy. ${ }^{16}$ Some of Corbett's exploits were recorded:

On the first morning [April 16, 1917] in the line, Lieut. P.E. Corbett took a patrol for several hundred yards along a shallow trench, which crossed No man's Land, to determine if the enemy still occupied Arleux Loop. By exposing himself at well chosen spots and at judicious intervals, Lieut. Corbett drew enemy fire, which convinced him that the trench in question was strongly held. Bombs ${ }^{17}$ were exchanged with a party of Huns, who were encountered, but, so far as the Canadians were concerned, no damage was done and the party returned safely at about 8.30 a.m. ${ }^{18}$

While there may be a certain unconscious humour displayed in these accounts both in the dated military tactics and in the phraseology employed, it is quite clear that junior officers were required to show a high order of courage on a daily basis. Some two weeks later, the following excerpt was recorded:

Meanwhile the Canadian artillery was active, shelling Fresnoy Village, Fresnoy Wood and the wire that protected these locations, in preparation for an attack by the infantry. In order to make sure the wire was well cut and that the Canadian battalions, when the time came, would not be hung up and slaughtered as at the Regina Trench, ${ }^{19}$ Lieut. P.E. Corbett and a party of 10 men conducted a daring daylight reconnaissance, as a result of

${ }^{15}$ Percy Corbett, "P.E.C. Diary, 1916," in Leaves from a Subaltern's Diary, McGill University Archives, $\mathrm{MG}_{4}{ }^{1}$ 95, Cont. ool. Since he gave the diary a title he may have contemplated publishing it at one time. In the entry for October 15, 1916, he writes: "Why I should have come through the whole shambles with a slight wound ... is a riddle I shall never be able to solve."

16 Paul Phelps Hutchison, Canada's Black Watch: The First Hundred Years, I 862-I 962 (Montreal: Black Watch (RHR) of Canada, 1962) at 96-98.

17 This, at least from the Canadian side, refers to the Mills bomb, a hand grenade with a serrated outer cover that forms shrapnel on detonation. It was invented by Sir William Mills (1856-1932) in 1915 .

18 R.C. Fetherstonhaugh, The 13 th Battalion Royal Highlanders of Canada, 19141919 (S.L.: Royal Highlanders of Canada, 1925), section 1 at 175 . Robert Clarke (see first unnumbered note) informed me that the Regimental archivist reported that the war diaries for the critical period of April and May 1917 are currently missing, so apart from Corbett's general service record only these published sources have been checked for details on his military career.

${ }^{19}$ Regina Trench was a position occupied by German forces near the village of Pys during the Battle of the Somme in October 1916. On the early morning of 
which the exact condition of the enemy wire was made known to those who were to control the attack. In addition, this reconnaissance assisted in clearing up and rectifying the obscure position on the left flank. ${ }^{20}$

The Battle of Arras ended, and the $13^{\text {th }}$ Battalion was relieved on May 3. On this date, Lieutenant-General Sir Julian Byng issued a special message stating in part:

Since the $9^{\text {th }}$ April, when the offensive against Vimy Ridge began, till the morning of May 3, when Fresnoy was captured and consolidated, it has been one series of successes, only obtained by troops whose courage, discipline and initiative stand pre-eminent.

Nine villages have passed into our hands. Eight German divisions have been met and defeated. Over 5 ,ooo prisoners have been captured and booty, comprising of some 64 guns, 106 trench mortars and 126 machine guns, are now the trophies of the Canadians. ${ }^{21}$

Shortly afterwards, it was announced that honours granted in recognition of gallantry for this battle would include the Military Cross for Lieut. P.E. Corbett. The citation to his decoration reads:

\section{Lt. Percy Elwood Corbett, Infy.}

For conspicuous gallantry and devotion to duty. He was sent out on a daylight patrol, and succeeded in bombing and driving in an enemy post. He made a careful examination of the enemy wire, and returned with most valuable information. ${ }^{22}$

\section{Corbett was wounded a second time in $1918 .{ }^{23}$ As Desmond Morton}

October 8, a number of battalions, including the Royal Highlanders, attacked the Regina Trench. The wire in front of the Royal Highlanders had not been properly cut by artillery barrage, and the battalion was caught up in the wire during the final charge. The soldiers were exposed to machine gun fire and cut to pieces. Thirteen of seventeen officers, and 288 of 360 men, who went forward in the attack, were casualties. R.C. Fetherstonhaugh, supra note 18 at 13941; G.W.L Nicholson, The Canadian Expeditionary Force, 1914-1919 (Ottawa: Queen's Printer, 1964) at 172-98; Canada in the Great World War (Toronto: Makers of Canada, 1917), vol. 4 at 74-78.

${ }^{20}$ R.C. Fetherstonhaugh, supra note 18 at 1 77-78.

21 Ibid. at 179 .

${ }^{22}$ London Gazette, Supplement no. 30204 (July 26, 1917) at 7644-45. The military records for this period all misspelled Corbett's middle name but this was a common error. For example, Humphrey in his tribute appearing later in this article and the McGill Directory of Graduates 1924 also used the spelling Elwood.

${ }^{23}$ E.A. Corbett, supra note 9 at 74 , reports: “[H]e served with distinction as an officer of the $13^{\text {th }}$ Highlanders of Montreal throughout the war. In February, 1918 , he was severely wounded, and, after several months in hospital, had proceeded to Oxford." Corbett's service record indicates he joined the $73^{\text {rd }}$ Battalion (RHC) in 1915 and only joined the $13^{\text {th }}$ Battalion (RHC) in July 1916 . There is a casualty report for him being wounded in August 1916 but not for the more serious second wound. 
wrote: "As a member of the $3^{\text {rd }}$ Brigade, $1^{\text {st }}$ Division, Corbett would have seen service at Lens and at Paschendale and his final injury in February 1918 would have occurred in an otherwise quiet period in the line. However, with intermittent shelling and regular patrol activity, nothing in the front line was ever completely quiet." ${ }^{24}$ This wound threatened Corbett's left hand, with which he wrote, and required some hospitalization in Canada. ${ }^{25} \mathrm{He}$ was discharged from hospital and the army just after the Armistice, and he immediately went to Oxford to take up his Rhodes scholarship.

\section{OXFORD: SCHOLARSHIP AND ROMANCE}

It is apparent that the thought of Oxford had sustained Corbett through the long years of war, and he went there with tremendous enthusiasm: "I was bursting with eager expectation. Here at last a dream, hopelessly deferred, abandoned almost, was on the point of realization. The world was given back to me. ${ }^{26}$ Corbett seemed to love everything about Oxford. He obtained a Bachelor of Arts in Jurisprudence with high honours. When he was subsequently elected a fellow of All Souls College, his elation knew no bounds. According to Dean J.E.C. Brierley, "[h]e had a fine sense of humour and great physical dexterity. He is reputed to have suspended himself by the toes in the Common Room of All Souls upon his election to a Fellowship." ${ }^{27}$ This story was also related in the memoirs of A.D.P. Heeney (1902-70).$^{28}$ Heeney entered Oxford as a Canadian Rhodes scholar in 1923 at a time when the story may have had some currency. Later, at McGill, Heeney studied under Corbett as a classmate not only of John Humphrey but also of Dean Brierley's father, James Gossage Brierley. This fact may account for how the story was handed down. Brierley and Heeney, both careful lawyers, used the word "reputed" when referring to this feat possibly because of its seemingly improbable

${ }^{24}$ Letter of Desmond Morton to author, March 25, 1999.

25 Corbett, supra note 8, "The First World War and I" at 2.

${ }^{26}$ Percy Corbett, "Impressions Mostly Oxonian," in Leaves from a Subaltern's Diary, McGill University Archives, $\mathrm{MG}_{4} 1$ 95, Cont. oo 1 , chapter 1 at 1 . These memoirs of Oxford University are a typed manuscript, divided into chapters, and possibly once intended for publication.

27 Dean J.E.C. Brierley, McGill Senate, November 23, 1983. Motion of condolence to Corbett's family.

${ }^{28}$ A.D.P. Heeney, The Things That Are Caesar's: Memoirs of a Canadian Public Servant (Toronto: University of Toronto Press, 1972) at 25. 
nature. In fact, the story is true, though the motive was not joy at election to All Souls but rather a combination of boredom and greed. In Corbett's own words:

One result ${ }^{29}$ was a wager in the All Souls betting book that has found its way into more than one memoir of Oxford. We thought the tone of the book needed a touch of levity, and on a night when only three of us were dining I proposed entering a bet that I would hang for five seconds by my toes from the top of the door in the Wren Room. It wasn't quite fair: they had no idea how prehensile my toes were, and agreed with alacrity. The stake was three guineas and the book records that I won with five seconds to spare.$^{30}$ The silly trick is, I'm sure, better remembered than the monograph on the Roman Law of Marriage that I was writing at the time. ${ }^{31}$

Corbett's election to All Souls College also meant a great deal to his family. His brother reported his father's reaction:

About this time an event occurred which gave Father greater pride and delight than anything that had ever happened to him ... A cable arrived for Father. I think it came from the Canadian High Commissioner in London, or some equally important personage, congratulating him on the election of his fourth son as a Fellow of All Souls College, Oxford. This, I believe, is the blue ribbon of Oxford. Father was enormously elated, and proceeded to tell everyone who would listen to him about this great new honour that had come to the family. He told me some weeks later, rather sadly, that most of the people he talked to would have been much more impressed if Percy had won the bucking-horse championship at the Calgary Stampede. ${ }^{32}$

It was also at this time that Corbett found romance. He had always admired McGill classmate Margaret Morrison from afar: "Margaret and I were in the same year at McGill but I scarcely knew her. I spent a great deal of time in Redpath Library and she was often there. From my place I would see her at the women's tables and

29 Of Corbett's friendship with Edward Bridges, son of the poet Robert Bridges.

30 The All Souls betting book does indeed record the matter for posterity as one intrigued reader discovered: "For a taste of their urbanity, I recommend the Betting Books which All Souls has privately published now and then ... The stakes are seldom high but the subjects are all-embracing ... There was once a bet to the effect that Home, Sweet Home was written by a divorced German Jew, and between the wars Corbett succeeded in proving that he could in fact hang upside down by the grip of his toes for 10 seconds on the common-room door." Jan Morris, Oxford (Oxford: Oxford University Press, 1987) at 63-64.

31 Corbett, supra note 8, "Some Oxford Friends" at 15-16. J.E.C. Brierley, in the motion of condolence, supra note 27, mentioned not only Corbett's athletic feat but also his first book on the Roman law of marriage, terming it a classic.

32 E.A. Corbett, supra note 9 at $73-74$. 
I became a silent admirer." 33 When he saw her again at Oxford in 1920 he was no longer the pre-war shrinking violet but the man who had impetuously drawn enemy fire at the Arleux Loop: "Coming home one day from golf at Cowley I was struck all in a heap to see her in Longwall Street. I leapt from my bike and accosted her ... From that day I knew I must marry Margaret if she would have me." ${ }^{34}$ Margaret Morrison, who was studying in Paris for the summer, was visiting a cousin in Oxford for the weekend. She had few defences against the new Corbett. He followed her to France and proposed marriage shortly thereafter in a canoe on the Seine. Mature reflection convinced him that a canoe was not perhaps the ideal location to pose questions that could draw uncertain responses and reactions, but the couple survived.$^{35}$ They were married in Beauharnois, Québec, in 1921.

\section{Corbett the Professor and Humphrey the Student}

After leaving Oxford, Corbett got a job as an assistant legal advisor in the International Labour Office in Geneva. He remained there for two years (1922-24) as an international servant before Sir Arthur Currie persuaded him to teach law at McGill. ${ }^{36}$ During this time, he became committed to the ideal of world government through international law and collective security, which was promulgated by the League of Nations. At McGill, Corbett taught courses in Roman law, the history of law, and international law. His Roman law course certainly made a distinct impression, though not always favourable, on his students. Decades after he had actually been in the class, Heeney recalled: "I have never sat under a

${ }^{33}$ Corbett, supra note 8, "Margaret" at 13.

${ }^{34}$ Ibid.

${ }^{35}$ Ibid. Corbett notes he "proposed, dangerously, in a canoe."

${ }^{36}$ Corbett stated that Currie persuaded him to come to McGill in his remarks for public consumption in E.A. Collard, ed. The McGill You Knew (Don Mills, ON: Longmans, 1975) at 227. This entry is cited more fully later in this article. David Corbett stated that his father returned to Canada because Margaret Corbett wanted to be closer to her family, then suffering the trauma of her older brother's suicide immediately followed by her father's death. He suggested that with his father's qualifications it was relatively easy to obtain a job at McGill, and it may be imagined that Currie would certainly try to help one of his former officers. David Corbett, "McGill," in Draft Biography of Percy Corbett, McGill University Archives, MG 4195, Cont. oo2, File 11, chapter 6 [that is, chapter 4], p. 1. This draft of a biography was never completed. It is divided into chapters but largely unpaged. 
better teacher. His lectures in Roman law were models of clarity and precision." ${ }^{77}$ Heeney's classmate, John Humphrey, did not concur. During his first year in law school, Humphrey carried an extremely heavy course load, consisting of five full courses in the Faculty of Law and four in the Faculty of Arts in order to complete his Bachelor of Arts - an equivalent of fifty-four credits. In addition to these courses, he had an active student life, serving as prime minister in the Model Parliament and president of the Literary and Debating Society. ${ }^{38}$ Under the stress of this exceptionally heavy course load, compounded by the stress of approaching examinations, he wrote to his sister on March 23, 1927:

The only thing that mars life right now is the thought of the nine examinations which are not far off. Did you ever hear of such a ridiculous number? I don't know whether I'll get through the week or not. Roman Law is the bug-bear of the lot. Justinian did civilization a service when he published his institutes, no doubt, but very few law students will admit it. It seems that we have to know more about Roman Law than the Romans did themselves. ${ }^{39}$

A third opinion on Corbett's Roman law lectures, which was also recollected, like Heeney's, years later in tranquillity, came from E.A. Collard, who attended McGill in the early 1930s:

Percy Corbett gave us a course in Roman law. He would come into the classroom with a huge tome under his arm. It was the Latin text of Justinian's Digest, from which he would translate whenever necessary with the utmost ease. Of course, none of us was up to this level of learning and it must be confessed that a good deal of what he said went over our heads. Nevertheless, it was an undoubted opportunity to have a prestigious subject presented to us by someone who fully comprehended its significance and who had established an international reputation in the field. ${ }^{40}$

Humphrey found Corbett remote and aloof in that first year. In retrospect, like Heeney and Collard, he gave a more balanced opinion. In an unpublished autobiography, Humphrey wrote: "There was no mistaking the fact that he was a great scholar but, during my undergraduate days, I did not particularly like him. Like most other students I put him down as a bit of an intellectual snob. My opinion of and regard for Percy Corbett would radically change

37 Heeney, supra note 28 at 25.

38 For the circumstances that obliged Humphrey to take on such a rigorous schedule, see A.J. Hobbins, "Dear Rufus: A Law Student's Life in the Roaring Twenties" (1 999) 44 McGill L.J. 753 at 757-58.

39 Ibid. at 763 .

40 Collard, supra note $3^{6}$ at 194 . 
over the years. Percy helped the process along as he gradually mellowed." ${ }^{41}$ Humphrey was not imagining things when he perceived both Corbett's coolness and his warmth. Corbett himself was aware of the dual personality he projected at different times. Two decades later, he attempted to explain this to his son, David, who was then serving with the Canadian Signal Corps in Australia:

I surely never was one for screwing confidences out of people. In fact I always supposed I was open to the opposite accusation - namely that my coldness repels confidence. If so, it was partly at least due to my respect for the independence of other personalities. Or am I romantically rationalizing what is really just a habit of absorption in my own selfish affairs? I never know. Anyway, I long ago reached a state of equilibrium where I'm pretty content to float, only half knowing either myself or anyone else. That's probably an effect of oncoming senility; but you've got to admit it's a comfortable kind of senility. I hope, if it continues, to be able to fade quietly out without too much trouble to myself or others. How's that for a final ambition? ... Few people come to me with their worries. I usually feel quite helpless but some of them have gone away with at least the illusion that they had a better notion what to do. Probably it was a case of people who knew in advance what I'd say and just wanted to have their own tentative conclusions confirmed by another human being. I suspect that's the motive that usually induces people to ask for advice. ${ }^{2}$

Humphrey, who was worried about his law courses in the spring of 1927, decided to devote all of his energies to studying law and to ignore his arts courses almost altogether. Despite these efforts, Humphrey found his examination results to be incomprehensible. $\mathrm{He}$ obtained a first class joint honours degree in economics and political science, while, in his law courses, he finished well down in the third division, among people he considered to be mediocre. ${ }^{43}$ It is to be imagined that Corbett, along with the other law professors, would not have had a particularly high opinion of Humphrey's academic performance at this juncture.

41 During the last few years of his life, Humphrey decided to write an autobiography recounting his entire life, since his previously published autobiography only covered the UN years. Tentatively titled "Life is an Adventure," this account is fairly complete up to the point Humphrey joined the UN in $194^{6}$. The autobiography is in McGill University Archives, "Life is an Adventure," MG 4127, Cont. oo8, File 133. This extract is from "Montreal: I Become a Quebecer," chapter 2 at $5^{6}$. See also Hobbins, supra note $3^{8}$ at 763 .

42 Letter of August 28, 1945 , "PEC Letters to DC," McGill University Archives, MG 4195, Cont. oo1. Warren Dicks (see first unnumbered note) compares Corbett's musings to Ambrose Bierce's definition: "Consult, v.t. To seek another's approval of a course already decided on," A Cynic's Wordbook (NY: Doubleday, 19o6).

${ }^{43}$ Hobbins, supra note $3^{8}$ at $765^{-7} 6$. 
In his second year Humphrey was able to devote far more time to the legal curriculum. He was no longer carrying all the extra arts courses and had somewhat limited his student activities. At the end of the year, he was in the first division, standing second in his class. ${ }^{44}$ Heeney's experience, however, was the opposite, and he wrote:

That first year I did well in my examinations. In the new environment my mettle was untried and the diversions at hand were relatively few. In the second year my resolution faltered and my academic record was less creditable. I had moved from the austerity of the Diocesan College up the street to my fraternity house where the atmosphere was rather less conducive to a severe schedule of study. Furthermore I had allowed myself to be caught up more in the life of the university and in the current gaieties of the English community which was in the full flood of prosperity and extravagance. ${ }^{45}$

In his final year, Humphrey kept up his good academic work, ultimately winning three prizes: the Bar Association Prize for Commercial Law, the Rowat Prize for Old French Law (he was the only candidate), and the Macdonald Travelling Fellowship. ${ }^{46}$ This success certainly drew him to the attention of the dean and possibly convinced Corbett that Humphrey should be an academic. Corbett was often on the lookout "to upgrade the quality of the professoriate by taking special interest in gifted students." ${ }^{47}$ Since there were no vacancies at McGill, Corbett approached a colleague, W.P.M. Kennedy, who was professor of law and political institutions at the University of Toronto, about the possibility of Humphrey being given an academic post there. On April 25, 1929, Kennedy wrote to Humphrey:

Dean Corbett kindly suggested to me that you might be interested in an appointment here in the graduating department of law. The subjects which you would have to teach would be Roman Law, Jurisprudence and History of English Law. This would technically occupy nine hours per week: but you would have very small classes indeed, and your work would be almost entirely personal. The remuneration would be a matter of arrangement for the administrative side of the University. However, I need not go into that question until I know whether you would be interested. It might be possible to interview you, but I do not wish to go to the trouble of making any such arrangement until I have some idea of what

\footnotetext{
44 Ibid. at 775 .

${ }^{45}$ Heeney, supra note 28 at 26.

${ }^{46}$ Hobbins, supra note $3^{8}$ at 776 .

47 Macdonald, supra note 5 at $26_{5}$.
} 
was in your mind. If you are interested in juridical science you would have an opportunity here to do creative work, and the burden of teaching would be light enough to allow you time for study and for writing. Indeed, I want to encourage scholarly and productive work. Before you reply, could you kindly take an opportunity to discuss this with Dean Corbett? ${ }^{48}$

Humphrey declined this offer for several reasons: he had political aspirations in Québec; the firm where he had articled - Wainwright, Elder, and MacDougall — had offered him a job beginning with a year's leave of absence; the Macdonald scholarship and the leave meant he could spend a year in Europe; and he really did not want to live in Toronto. ${ }^{49} \mathrm{He}$ went into private practice for several years, but Corbett did not give up on wooing him to the academic cause.

\section{The INTEllectual LefT duRING THE GReAT Depression}

In August 1931, Corbett took his young colleague F.R. Scott to the annual meeting of the Institute of Politics at Williams College in Massachusetts. Corbett introduced Scott to an acquaintance from the University of Toronto, historian Frank Underhill, and later accompanied them on a long walk up Mount Greylock. Scott and Underhill found themselves to be kindred spirits, who both had a keen interest in discussing the need for a type of Fabian Society in Canada: "Although Corbett largely shared the concerns of his two companions, he became almost a spectator as Scott and Underhill bounced ideas off each other." ${ }^{50}$ From this meeting, the League for Social Reconstruction (LSR) was born. Members of the league were active throughout the 193 os in Montreal and, in

48 Certain letters, such as this one, have not yet been donated to McGill University Archives and are currently in the author's possession as Humphrey's literary executor. When these letters are cited, the title "Humphrey correspondence" and a date are simply given. For an excellent appreciation of Kennedy, a Tudor historian for the first two decades of his academic career, see R.C.B. Risk, "The Many Minds of W.P.M. Kennedy" (Summer 1998) 48 U.T.L.J. 353.

49 Humphrey had moved to Toronto in $19^{2} 5$ to attend Osgoode Hall Law School but stayed less than a week as he quickly developed a strong aversion to the city. Humphrey, supra note 41, "Montreal: I Become a Quebecer," chapter 2 at $4^{6-}$ 48. See also A.J. Hobbins, ed. On the Edge of Greatness: The Diaries of John Humphrey, First Director of the United Nations Division of Human Rights (Montreal: McGill University Libraries, 1994), chapter 1 at $14^{-1}$, and Hobbins, supra note $3^{8}$ at 757 .

${ }^{50}$ Michiel Horn, The League for Social Reconstruction: Intellectual Origins of the Democratic Left in Canada, 1930-1942 (Toronto: University of Toronto Press, 1980) at 21 . 
particular, at McGill University. In addition to Scott, the McGill contingent included such notable individuals as Leonard Marsh, King Gordon, Eugene Forsey, and, as a student, David Lewis.

When Humphrey left Montreal in 1929 for his year in Europe, he was a conservative with liberal inclinations. When he returned, he found Montreal in the throes of the Great Depression. He saw first hand the misery of hunger and unemployment and even felt guilty about having a job with a prestigious law firm. He expressed his anger and frustration to his sister on May 2, 1932: "We're all sweating from the first to the last, under fear of losing our jobs ... Of course, I am one of the fortunate ones. I live in comparative security; but there are those who don't. When I think about these things - it's not theorization. Unfortunately there are too many concrete examples all around us - I want to go out and tear someone to pieces." ${ }^{51} \mathrm{He}$ had known Scott, whom he had greatly admired, as a fellow student and as a professor. ${ }^{52}$ It did not take him long to join Scott in the LSR and to become a committed socialist, dedicated to the proposition that governments have an obligation to protect their citizens from social and economic hardship. He got to know the left-wing elements at McGill through the LSR, coming especially under the influence of King Gordon. Two decades later, Humphrey recalled this relationship:

On Friday evening King and Ruth Gordon (and their son Charlie ${ }^{53}$ ) entertained Mary Tenison-Woods, Molly [Margaret] Bruce and myself for

${ }^{51}$ R. St. J. Macdonald, "Leadership in Law: John P. Humphrey and the Development of the International Law of Human Rights" (1991) 29 C.Y.I.L. at 1o, note 6 .

52 Humphrey's letters to his sister during his undergraduate years contain many admiring references to Scott. See Hobbins, supra note $3^{8}$ at $759-60,762-63$, and 764 . Scott's biographer states he "taught a number of young men whose future careers were, to some degree, influenced by concepts of law absorbed from Scott" including Humphrey. Sandra Djwa, The Politics of the Imagination: A Life of F.R. Scott (Toronto: McClelland and Stewart, 1987) at 236. Scott's first year as a professor was 1928/1929, which was also Humphrey's last year as a student.

${ }^{53}$ Charles "Charley" Gordon (1940-), Canadian journalist and author, was returning with his family from Egypt, where they had resided since 1956, to Canada. Owing to the political uncertainties caused by the Suez Crisis he had been obliged to complete high school education in Beirut. He was about to begin his studies in political science at Queen's University in Kingston, Ontario. After graduating from university he was managing editor of the Brandon Sun, before joining the Ottawa Citizen in 1974, where he is still a columnist. He has written four books, the most recent being The Canada Trip (Toronto: McClelland and Stewart, 1997). He married Nancy Thain in $196_{5}$. 
dinner. I took them to the Bavaria later for drinks. It was a good party and I enjoyed myself. But my relationship with King will never be confident and frank again. Whenever I am with him I am on my guard, full of hesitations and even distrust. I remember Jeanne once saying about King in the early McGill and L.S.R. days - that if she ever lost her confidence in him she wouldn't have much belief left in the human race. What a hero he then seemed, almost a paragon of virtue and moral courage? ${ }^{54}$

In the mid-193os, Humphrey also began to become interested in international law. This interest was clearly stimulated and encouraged by Corbett, who perhaps had his own agenda. While F.R. Scott could be viewed initially as a Corbett protégé, Scott had little interest in international law, and, as a result, he and Corbett were growing politically apart. Corbett began to view Humphrey as his potential successor. Humphrey demonstrated his growing enthusiasm for the subject in a series of letters to his sister:

I myself have a real reason for not keeping up my correspondence. I have become intensely interested in a subject, international law, which is taking up every spare moment that I have. It means work practically every night. Jeanne will soon have me in the divorce courts. Keep it under your hat but I'm seriously thinking of trying for my M.C.L. ${ }^{55}$ Dean Corbett says that I could do it in two years ... Thanks very much for the birthday gift. Lauterpacht is one of the most important contemporary English writers on international law. Corbett says that this particular book: "Functions of Law in the International Community" is the most important contribution to the modern English literature on the subject. ${ }^{56}$

And a few months later:

I have - with the exception of the three weeks holiday - been working like a Trojan ever since last May, reading tomes and tomes on International Law. Incidentally, if Italy gets away with the Ethiopian racket, it will be about the end of international law in our time. What do you think of it? Sir Samuel Hoare's ${ }^{57}$ speech before the Assembly encourages me

54 "Humphrey Diaries," July 6, 1958, McGill University Archives, MG 4127 , Cont. 20, File 414. Humphrey gave a job in the UN Division of Human Rights to Gordon in 1949. He was hurt that Gordon left the division in 1954, causing great difficulties in what Humphrey considered its hour of greatest need. As a result, Humphrey revised his opinion of the man he had so greatly admired in the 193 os, and the diary entry concludes with the sentence "And how disappointing my experience with him turned out to be."

${ }^{55}$ Corbett had recently re-instituted the Master of Civil Law (M.C.L.) programme with a view to enhancing legal scholarship in the faculty. Macdonald, supra note 5 at 266.

${ }^{56}$ Humphrey correspondence, supra note 48, May 30, 1935 .

${ }^{57}$ Sir Samuel Hoare, Viscount Templewood (1880-1959) was British secretary of state for Foreign Affairs in 1935. On September 11, he made a major policy 
somewhat. If France supports the League, not only is Mussolini finished, but the League becomes the strongest force in international politics, and the biggest step forward is made in the development of the reign of law and order that has ever been made. I'm almost afraid to hope - so much depends on it. ${ }^{58}$

This interest finally led to his enrolment as a part-time student, while retaining his job in the law firm:

I have registered in the Graduate School at McGill. I am taking my first lecture - which is really a private conference with Dean Corbett tonight. This is very interesting but it keeps me moving. The reason why it is more exciting being a socialist in Montreal is because it is perhaps more dangerous. The associate here at the office who is immediately above me called me a "snake in the grass" this morning for having C.C.F. sympathies while accepting capitalist money. ${ }^{59}$

\section{INTERNATIONALISM AND THE BREAK WITH THE LEFT}

Corbett had been well disposed to many of the aims of the LSR, but he never joined it. ${ }^{60}$ As an international lawyer, he sought solutions for all of mankind and did not concentrate merely on Canada and its problems. For a number of years, his ideas were in a state of peaceful co-existence with the views of the LSR elite, but eventually a break came. The reason for Corbett's break with the intellectual left was to be found in the platform of the newly founded socialist party, the Cooperative Commonwealth Federation (CCF). While the LSR had discussed many abstract ideas, the CCF was obliged to come up with hard policies to contest the 1935 election. After much debate, the CCF concluded that Canada should pursue an isolationist foreign policy of neutrality regardless of what events took place abroad. This policy proved to be divisive even within the $\mathrm{CCF}$, and it alienated those individuals, including Corbett, who believed the best road to peace lay through the League of Nations and a policy of collective security. On this issue, socialists were to find out that with Corbett they were not simply dealing with a benignly absent-minded professor but also with a decorated veteran

speech to the League of Nations Assembly in which he pledged that Great Britain would "maintain their support of the League and its ideals as the most effective way of ensuring peace." Keesing's Contemporary Archives, volume 2 (1935-36) at 1788-179o. Over the next few days, the majority of members, including France on September 13, followed Hoare's lead and declared their support for the covenant.

${ }^{58}$ Humphrey correspondence, supra note 48, September 12,1935 .

${ }^{59}$ Ibid., October 8, 1935.

${ }^{60}$ Corbett, supra note 36 , "McGill," chapter 6. 
who had strong ideas on what sacrifices had been made, and would have to be made, in dealing with aggression. Corbett published a strong attack on the CCF position:

Every day we are being urged not only to stay out of the war into which international complications threaten to draw Great Britain, but to have no part or parcel in the League of Nations "as now constituted" or "in its present form." This attitude of reproachful waiting appears now to have been officially adopted by the C.C.F. as its "platform" on foreign policy. It is justified by a formidable recital of the familiar banalities about economic competition, the struggle for raw materials, peaceful change, and the use of the existing League as a screen behind which "imperialist governments ... play the old game of power politics."

Nothing could be more legitimate at this time than criticism of the record of the League of Nations. But vague resolutions on "providing machinery for peaceful change of treaties; dealing fearlessly with economic conflicts; working out in advance a clear policy for collective action against an aggressor ..." are of very little use except as general directives for a loyal member of the League seeking by all means at its command to strengthen that organization from within. ${ }^{61}$

Corbett's views on isolation and neutrality versus collective security did not, of course, mean that he believed Canada should automatically become involved wholeheartedly in any British war, even though the Canadian status would be that of a belligerent. His focus was on the League of Nations, not the Empire. He clarified the distinction as follows:

If war comes, we may ... be called upon as a member of the League to participate in military action against the nation or nations responsible for its outbreak. In that event we ought to fulfil the whole obligation a reasonable interpretation of the Covenant casts upon us...

If, League or no League, Great Britain is involved, we should accept the position of belligerent. Whether, and how far, we shall contribute to the prosecution of the war should depend upon the majority opinion of our people as to our own danger, the justice of the cause, the need of Great Britain, and our power, economic and political, to meet that need. ${ }^{62}$

Within a year, Corbett's thinking had evolved to the point where he felt that Canada could avoid the status of belligerency by making a declaration of neutrality when Great Britain declared war. ${ }^{63}$

${ }^{61}$ P.E. Corbett, "Isolation for Canada?" (1936-37) 6 University of Toronto Quarterly 120.

${ }^{62} \mathrm{Ibid}$. at 130 .

${ }^{63}$ F.R. Scott clarified Corbett's position in an obscure footnote in a work prepared in 1938 , stating that "Professor P.E. Corbett has expressed his opinion to the author that Canada now has a right to declare neutrality but agrees that unless 
The ideological split between Corbett and the intellectual left proved to be a watershed for Humphrey. He had spent the early years of the decade utterly committed to the ideals and ideas of socialism, especially those of Scott and King Gordon, who had dreamed of building a utopian social democracy, but only within Canada's borders. Now he was almost forced to choose between this introspective socialist position and the seemingly more mature and universal views of Corbett, who painted with a broader brush upon a larger canvas. It was a decision of enormous importance to his future career. Following Corbett's lead as he so often did, Humphrey chose to devote his time and whatever talents he possessed to the international arena, understanding that peace and security must be guaranteed for all, not just for Canadians. He summarized his rejection of Canadian socialism years later in his diary: "My experience, even in Canada, has been that socialists are so preoccupied with the domestic questions that they had no energy and time left for what is happening in the international community. This is true even of as enlightened and intelligent [a] person as Frank Scott." ${ }^{44}$ Humphrey left the LSR and did not join the CCF. His name was never later associated with these groups although, at heart, he remained a socialist. It was partly because his earlier associations with the socialist movement were unknown that he was able to survive the attacks on the UN Secretariat staff by the various groups who investigated un-American activities in the post-war years and thereby remained a player in the UN human rights program. ${ }^{65}$

\section{Recruiting Humphrey as a Colleague}

Corbett had been a mentor to Scott, recognizing the latter's brilliance during his first few years on faculty at McGill. By the mid1930s, he found that not only had they grown apart ideologically

she does so there will be a presumption of belligerency against her." F.R. Scott, Canada Today: A Study of Her National Interests and National Policy (London: Oxford University Press, 1939) at 131 , note 1.

${ }^{64}$ Hobbins, supra note 49 , vol. 2 at $262-63$.

${ }^{65}$ For a more complete examination of this question, see A.J. Hobbins, "Humphrey and the Old Revolution: Human Rights in the Age of Mistrust" (1995) 8 Fontanus 121. Although Humphrey did not realize it for many years, Scott felt Humphrey had let him down at this point and also when Humphrey accepted the deanship after Scott had been passed over in 1946. Humphrey, supra note 41, "My Initiation As an International Official," chapter 6 at 117. 
but also that both Scott and the other full-time faculty member, C.S. Le Mesurier, were wedded to the civil law side of the faculty and tended to oppose any initiatives on the common or international law side ${ }^{66} \mathrm{He}$ began to perceive Humphrey more and more as the colleague and successor that Scott could never be. The "private conference" that had constituted Humphrey's first lecture became a weekly event. While Corbett may have appeared to show "remarkable generosity" with his time spent on the "gratuitous job of tutoring" Humphrey, ${ }^{67}$ he clearly had reasons of his own. Indeed, it was not long before he suggested to Humphrey the possibility of joining the faculty. When Humphrey wrote to his sister to advise her that he might become a professor, gradually replacing Corbett, Ruth Humphrey appears to have thought that that also included becoming dean. Humphrey clarified matters for her:

A propos of that [the possibility of joining the Faculty of Law], I had another conversation with the Dean last Tuesday. It is apparently only a question of having the principal's approval; but the Dean doesn't expect that [we will] finally know until some time towards the end of January, as the principal is pressed with other matters. Your suggestion that $\mathbf{I}$ might be Dean myself was somewhat ludicrous. The law faculty isn't a one man affair! There are three full time men - including Frank Scott, who has one of the most brilliant minds in the country - and at least half a dozen lawyers from down town. I will be very much of a junior when and if I begin; but there is no telling, of course, what secrets the future may hold. ${ }^{68}$

By the following month, Corbett had opened his mind to Humphrey more fully, and Humphrey had virtually decided to become an academic. He told Ruth:

I still have no official news about the university job. Nevertheless, the de facto situation is about as follows: over a week ago I had lunch with the new principal ${ }^{69}$ and Dean Corbett at the Faculty Club. Nothing whatever was said about the job, but I talked to the principal for over two hours. Since then, Corbett has told me that I can count on the job, and was supposed to have confirmed officially today. I haven't heard from him yet. This means nothing, however, for he is one of the most absent-minded men that I have ever met.

Our conference last night was devoted not to international law, which I have been studying with him, but to Roman law, which will be the most important subject that I will have to teach. Add to this the fact that he told

\footnotetext{
66 Macdonald, supra note 5 at 267 and 289 , note 179 .

${ }^{67}$ Macdonald, supra note $5^{1}$ at 11.

${ }^{68}$ Humphrey correspondence, supra note 48, December $13,1935$.

${ }^{69}$ A.E. Morgan.
} 
me not to pay this term's fees for the graduate course (which I will not complete if I get the job) and you will have a fair idea how the ground lies.

The reason they have taken such a long time to decide is apparently because other more important things had to be decided first. For example, if it were decided to get a new dean from England to replace Corbett, the new man would do the work that I am now to do, which would, of course, mean that there would be no place open for me. As it is, LeMesurier will apparently be made dean, although this also is not yet official.

Corbett will not leave the university absolutely for a few years at least with the result that up until his final departure he and I will share the work (and the salary, I believe) that he is doing now, although I will be expected to lecture in Civil Law.

Corbett's idea, you see, is to gradually get rid of all administrative work and lecturing so that he can devote all his time to writing.

My present plans - which are still, of course, quite secret - are to leave Montreal next Fall in time to be in Paris for the opening of the university year on Nov. 1 st. I will follow the course for a doctorate in international law, but having regard to the work that I will be obliged to do in Roman law, Latin and German, [I] will, in all probability be unable to complete my thesis by the Spring, which will mean that I will have to return to Paris probably in the Summer of 1938 . However, it may be possible to arrange otherwise ...

P.S. The Dean called a few minutes ago (Jan. 24) and confirmed our understanding. I think it preferable, however, to keep quiet about it a little longer, i.e. until the appointment is regulated. I will be appointed lecturer now and given a leave of absence for a year. ${ }^{70}$

Corbett may have been a little premature here since his letter to Principal Morgan telling of Humphrey's willingness "to sacrifice his very distinguished prospects at the Bar" is dated January 30, $1936 .^{71}$ However, within a month, Morgan had written to offer Humphrey the job, including a grant of two months salary towards the cost of his studying in Europe. Morgan outlined the conditions in the following fashion:

The question of your appointment in the Faculty of Law has now been considered, and subject to confirmation of the Board of Governors I have pleasure in offering you a post as Lecturer in Law for the period of two years from the first of September 1936.

During the first year you will be given a leave of absence to travel and study in Europe and the University is willing to make you a grant of $\$ 500$ towards your expenses in this connection.

As from the first of September 1937 you are offered a salary of Three Thousand $(\$ 3$, ooo.oo) Dollars a year.

The post is probationary in so far as the appointment is limited in

${ }^{70}$ Humphrey correspondence, supra note 48, January $23,1936$.

${ }^{71}$ Macdonald, supra note $5^{1}$ at 11 , note 17. 
period but the intention is that if the arrangement seems to be satisfactory on both sides it will be continued and eventually made permanent.

I hope very much you will see your way to accepting the position.

Yours sincerely,

A.E. Morgan,

Principal and Vice-Chancellor. ${ }^{72}$

Humphrey accepted on February 26, and the Board of Governors approved this appointment at its meeting on March $3,193^{6 .}$

\section{Humphrey's Year in Europe}

Two problems faced Humphrey during his leave of absence. First, he needed more money for his expenses in Europe than the McGill grant of $\$ 5$ oo afforded and, second, he was unsure how he could obtain the doctorate within the time frame of a year. Corbett was able to use his contacts in the large network of academic international lawyers to help with the first problem. On February 11, 1936, he wrote to his colleague, James Brown Scott (1 866-1943), who was a professor of international law, jurisprudence, and Roman law from 1933 to $194^{\circ}$ at Georgetown University, in an attempt to secure further funding for Humphrey. Scott, one of America's most distinguished international lawyers, was a founding member of the American Society of International Law (19o6), serving as its secretary from 1906 to 1924 and as its president from 1929 to 1939 . He was the founder and editor (1907-24) of the American Journal of International Law. Most importantly, he was a founder and permanent secretary (1911-40) of the Carnegie Endowment for International Peace. Corbett's letter showed the very high regard in which he held Humphrey as a potential academic:

I understand that Mr. J.T.P. Humphrey, who graduated from this Faculty in 1929 , is applying for one of the Carnegie Travelling Scholarships or Fellowships in International Law. He was one of our most brilliant students, graduating with first class honours, the Bar Association Prize for Commercial Law, the Rowat Scholarship for Old French Law and the Macdonald Travelling Scholarship. After a year's study in France he returned and went into practice here. After five years of successful practice, he has come to the conclusion that his principal interest lies in the investigation of abstract legal problems, and desires to change over to an academic career. Having reached that conclusion, he came to me almost a year ago for direction in the study of international law, and after a summer's intensive reading, entered last October as a candidate for the degree of Master

${ }^{72}$ Humphrey correspondence, supra note 48, February 22, 1936. 
of Civil Law. Since October he has been working with me upon contemporary legal science and its application in the field of international law. I have found him one of those rare students who can contribute at least as much to the teacher as the teacher to him.

As I am contemplating early retirement from the greater part of my academic work, I am recommending to the University authorities that Humphrey should be employed to take over a share at least of my teaching. As soon as official action has been taken in the matter, I shall be glad to inform you. In order to qualify himself, Humphrey will require a year's special leave, preferably in England or on the continent of Europe. It will be necessary for him to lecture in Roman law, and one of his purposes abroad will be to acquaint himself with what is going on in Romanist scholarship at the moment. His main interest will always be directed to international law, but you will probably agree with me that training in Roman Law and in abstract legal science are an excellent preparation for teaching in his favourite subject.

I do not know whether his application will fall easily into any of your recognised categories of subsidy. My letter is therefore addressed to you largely because of the tremendous personal interest which you have in the furtherance of international law. Here is a young man with great ability and great keenness. If he is given the encouragement he needs, he will count enormously in the development of international studies in Canada. In fact he is precisely the sort of person who would be capable of starting and making a success of a society of international law here, an object which, I know, lies close to your heart. If the Carnegie Foundation offers any possibility of assisting him, I feel sure that he will prove worth anything that can be done for him.

With this type of support from a man of Corbett's eminence addressed to precisely the right, and at the time even more eminent, quarter, Humphrey's application for funding was almost a foregone conclusion. On April 7, 1936, the Montreal Gazettecarried the announcement that Humphrey had been awarded a Carnegie fellowship valued at \$200o. Whether or not Humphrey's application might have succeeded on its own merit, Corbett's testimonial rendered the matter moot.

The second problem concerning Humphrey's doctorate was less easy to resolve. He found he could obtain the degree by staying an extra three months in Paris until the end of 1937. To accomplish this, he would need the permission of the McGill authorities to extend his leave, and he would have to obtain further financing. He began his campaign by bouncing the idea off his colleagues in the faculty - Scott, Corbett, and the new dean, Le Mesurier. Scott was enthusiastic, responding:

I have seen letters of yours to Corbett and LeMesurier, and am glad to know you are having an interesting time. I think you are right to take the 
extra year necessary for your degree, if you can manage it. It is a small time in relation to your future academic career, for which the degree and the work in Paris will be invaluable.

Nothing of special note is happening here. The job of surveying and reorganizing the work of the university is going steadily under Morgan, who in this respect is first rate. LeMesurier will make a good Dean if he keeps well; he has lots of ideas. We are pursuing the idea of a school of government. ${ }^{73}$

Le Mesurier's response was less encouraging. While McGill was prepared to extend the leave, there would be no further financial help nor could Humphrey receive his salary and make the time up later. The dean suggested that Humphrey seek further aid from the Carnegie Endowment. He also gave him some interesting opinions on the value of a doctoral degree:

Since I last wrote to you I have discussed your position with Corbett and the Principal and we are willing to extend your leave of absence until the beginning of the second term next session - or until September $1^{\text {st }}$ following at your option. In either case your salary would begin on the date you reported for duty. If you need additional financial help it will be necessary to obtain this from the Carnegie or some other outside source as the University does not see its way to continue Corbett's salary and give you any extra help. The suggestion that the work you miss next fall could be made up later does not appeal to us. Both Corbett and the Principal think that if the men under whom you are working at Paris give satisfactory reports of your progress the Carnegie people would be quite likely to give you an additional grant to enable you to complete the job.

I realize of course the value of the degree to you in the event of your applying for a position in another university. We ourselves attach very little importance to it. This may be sour grapes but there it is. ${ }^{74}$

In general, Le Mesurier does not appear to have been particularly interested in the scholarly aspects of legal education during his term as dean:

While he served in a full-time capacity [as dean] ... he was not a scholar and did not see either academic writing or the graduate programme as central to legal education. Nor did he have Corbett's optimism about the potential of non-jurisdictional courses such as international law and the merits of inter-Faculty exchange. Lemesurier's primary intellectual loyalties were to the Bar and to the notion that the faculty's overriding mission was to train future advocates. ${ }^{75}$

${ }^{73}$ The full text of this letter of February 14, 1937 is published in A.J. Hobbins, "A Frank Scoti Leiter from 1937" (1998) 1 1 Fontanus at $112-15$.

${ }^{74}$ Humphrey correspondence, supra note 48, January 8, 1937.

${ }^{75}$ Macdonald, supra note 5 at 567 . 
When it transpired that the Carnegie Endowment would give no further funds and that Humphrey would have to abandon the doctoral project, Corbett tried to soften the blow:

I have your two letters of the $20^{\text {th }}$ and $24^{\text {th }}$ of February, and regret very much for your sake that the Carnegie Foundation [sic] will not contemplate extending your fellowship. It occurs to me, however, that as these fellowships are being discontinued you were exceedingly lucky to be going abroad this year instead of next.

As far as I am concerned I shall enthusiastically welcome the greater liberty that your return will give me. I believe that the plan is for me to keep some of my subjects, rather than throw the whole load upon you in your first year. You will doubtless receive detailed information about these matters from the Dean.

I should not be too much perturbed by the circumstance of not being able to proceed at once to the doctor's degree. You have only to keep your mind reasonably fixed on your subject to achieve the equivalent of the degree by your actual contributions. ${ }^{76}$

Le Mesurier stated that his recollection was that he had consulted with Corbett on this issue and that Corbett had indicated that he did not wholeheartedly support Humphrey's request to stay one more semester in Paris. When Le Mesurier wrote "[w]e ourselves attach very little importance to it," he appeared to be speaking for Corbett as well himself, which was seemingly odd, given the vastly different way the two men viewed scholarship. If Le Mesurier's use of the pronoun "we" did indeed indicate consultation with Corbett, as opposed to some expression of decanal royalty, a clue to the scholar's reasoning may be found in something that he had written over fifteen years previously. While completing his Rhodes scholarship, he had greatly admired the Oxford approach to higher learning even though it resulted in the same degrees, Baccalaureate and Master's, that he had obtained at McGill University. He considered individual experience and accomplishments to be more important than degrees, and he summarized these thoughts in a private journal:

It may not be mal à propos here to interpose a word on the immense importance we [North Americans] attach to degrees, and the faith with which we accept this purely prima facie evidence of attainments. In England, degrees attract comparatively little attention; are much less decisive factors in the choice between candidates even for an academic position ...

The $\mathrm{D}$. Ph. recently established at Oxford is designed to attract the transatlantic student, and to crown his labours with a palpable reward. It

${ }^{76}$ Humphrey correspondence, supra note 48, March 9, 1937. 
is devoutly to be hoped that this is not a step, in England also, towards estimating a man's knowledge by the letters after his name. ${ }^{77}$

When Humphrey finally obtained his doctorate in 1945 , it was from McGill University in the field of political science and after Corbett had gone to Yale University. While Humphrey may have been disappointed by the events of 1937 , this circumstance did allow him to claim a unique McGill distinction - four different degrees from four different faculties: Commerce, Arts, Law, and Graduate Studies. He returned to teach in October 1937 and remained in the Faculty of Law until he went to the UN in August 1946.

\section{Corbett's Retirement From McGill}

Corbett carried out his plan outlined to Humphrey in 1935 of retiring early from McGill. He took leaves of absence in the United States during the early part of the Second World War and retired in 1944 after returning for one year. His reasons were not altogether clear. Various explanations have been offered including ill health, dissatisfaction with the esteem in which international law as a discipline was held in Canada, disappointment at not being named principal, and general unhappiness with the political climate at McGill. It may have been a combination of several of these factors.

Corbett's health could not have been a major reason to leave. Although he continued to suffer from eye trouble,${ }^{78}$ he did not let this hinder his subsequent career of great distinction at McGill and elsewhere, anymore than he allowed it to prevent his military service two decades earlier. By 1934, he found the eyestrain associated with his daytime administrative work so great that he could only continue his research by having his family read to him at night. He confided to a European colleague:

Nevertheless it is essential that I take good care of my eyes. I live something like a monastic life, staying at home in the evenings and being read to, in order to be able to do a decent day's work ...

In the near future I shall have to do one of two things - either retire from the University completely or at least be relieved of this deanship. So much of it seems to me a waste of time, and there are thousands of things I want to do. ${ }^{79}$

${ }^{77}$ Corbett, supra note 8 , chapter 8 at $5^{-6}$.

70 Macdonald, supra note 51 at 11 .

${ }^{79}$ Letter of Corbett to Professor F. de Zulueta, April 26, 1934. In this letter, Corbett confesses that he had not been able to work on his research project - a 
Other than eye trouble, his health seems to have been remarkable, and he remained active and robust late in life ${ }^{80} \mathrm{Health}$ was almost certainly one of the reasons Corbett tried to avoid administrative duties, but it was not one of the reasons he chose to leave McGill.

The relative importance of international law as a discipline at McGill and in Canada may have been more of a factor. Despite the eminence of the international law programme at McGill, it always took second place to the study of civil law in the view of the majority of Corbett's colleagues. F.R. Scott fought any expansion of the McGill program beyond civil law as strongly in the 1930s as he would do decades later when Maxwell Cohen began advocating the National Programme. ${ }^{81}$ Le Mesurier not only held similar views to Scott on the teaching of civil law but also, as has been seen, held legal scholarship in generally low esteem. Only Humphrey, the protégé, shared any of Corbett's views on the importance of international law in the McGill curriculum. Yale and Princeton, where Corbett went to work after leaving McGill, both offered far more scope for research and recognition in the discipline of international law, and it was at those institutions that he produced the large part of his scholarly output. ${ }^{82}$ Nonetheless, with the appointment of Humphrey, Corbett had established a situation where his teaching load was reduced in fields of lesser interest to him and where he could concentrate more on research in the areas of his choice. Under these circumstances, he probably intended to remain at McGill for an indefinite period.

The question of the principalship and the general political climate at McGill were inextricably linked. Throughout the 193os, there had been tension between the left-wing members of the faculty and the conservative elements of the university administration,

textbook - for two years. Complete letter appears in D. Corbett, supra note $3^{6}$, "McGill," chapter 6.

${ }^{80}$ Kathy Fisher (see first unnumbered note) said that he still did chin-ups in his seventies. Professor J.E.C. Brierley recalls going with F.R. Scott to visit Corbett when he was in his late eighties, at which time they found Corbett outside chopping wood.

${ }^{81}$ Macdonald, supra note 5 at 289 . Many people found Scott to be something of an enigma. On the one hand, he was a passionate and compassionate poet and libertarian, but on the other hand, as a legal educator, he was often conservative, narrow-minded, and authoritarian. As Macdonald aptly put it in a recent conversation: "Scott did not have a fully integrated personality - keeping these two aspects of his life compartmentalized."

${ }^{82}$ Brierley, supra note 27. 
represented, in particular, by the chancellor, Sir Edward Beatty, and the Board of Governors, epitomized by J.W. McConnell. It fell to the principal to steer a course between these two extremes and to resolve questions of employee duties versus academic freedom. It was generally considered that Sir Arthur Currie had filled the role admirably. Eugene Forsey, who was at this time a lecturer in economics, known for his left-wing views, considered Currie to be "head and shoulders above the other three" - A.E. Morgan, Lewis Douglas, and Cyril James - under whom Forsey worked. ${ }^{83}$ Corbett said of him: "It was Sir Arthur Currie who persuaded me to come from the League of Nations to teach Roman and international law. I always had the warmest feeling for the man. A number of us were involved in a series of skirmishes for professional freedom of speech and publication, and I never knew him to fail us. He was no academic, but he combined what seemed to me a true sense of values with an earthy realism." ${ }^{84}$ Currie, whose health had never recovered from his collapse in 1928 following a setback in litigation over his war record (a libel suit that he did in fact win), died at the end of 1933. Thus began a seven-year period in which three principals were appointed, the first two following significant interregna. Indeed, the turnover in principals was so rapid that one person suggested that McGill had established a "new two-year course leading to the degree of Ex-Principal." 85 The chancellor therefore provided an element of stability during what has been termed "the Decade of a Chancellor." 86

Chancellor Beatty took over the direct administration of the university upon Currie's death, announcing there was no need for an acting principal since he would be available on a daily basis. ${ }^{87}$ As president of the Canadian Pacific Railway, Beatty was used to compliant and obedient employees - indeed, this was true for many of

${ }^{83}$ Eugene Forsey, A Life on the Fringe: The Memoirs of Eugene Forsey (Toronto: Oxford University Press, 1990) at 27.

${ }^{84}$ Collard, supra note 36 at 227 . There is some evidence that Corbett needed little persuading to come to McGill (see the text contained in note $3^{6}$ ).

${ }^{85}$ Hugh MacLennan, ed. McGill: The Story of a University (London: Allen and Unwin, 1960) at 101 .

${ }^{86}$ Stanley B. Frost used the phrase as a chapter heading in his McGill University: For the Advancement of Learning, volume 2 (Montreal: McGill University Press, 1984), chapter 7 at $187-209$. Michiel Horn, Academic Freedom in Canada (Toronto: University of Toronto Press, 1999), devotes a chapter entitled "Socialism and Academic Freedom at McGill" to this period.

${ }^{87}$ Frost, supra note 86, vol. 2 at 190. 
the McGill governors. He was never quite at ease with the concept of academic freedom, although he had learned about the importance of the concept well enough in his years as chancellor. There is also evidence that, unlike McConnell, he did not have any deepseated prejudice against socialists. ${ }^{88} \mathrm{He}$ became increasingly upset with the public pronouncement of the radical elements of the faculty, whom he believed to be a vociferous minority, because he felt it brought the university into low esteem with the public. When A.E. Morgan was hired as principal in the summer of 1935 , Beatty tried to get him to encourage faculty that were opposed to the left - the silent majority in Beatty's view - to answer the public statements of people such as F.R. Scott. Morgan, however, proved far less tractable than anticipated and showed a genuine belief in academic freedom. He demonstrated this in a response to Beatty:

It may well be that university teachers, readier with the tongue and the pen, are more prone to expression of their ideas. Yet I doubt whether they are really as prolific verbally as the politicians.

I am glad you write to me, although I have no solution to offer for a problem which I hope will always be with us. I hope, because as I see it the only condition of its solution is the establishment of an authoritarian state, which God forbid!... All we can actually do is to impress on them at all seasons that rights imply responsibilities. ${ }^{89}$

This stand, however, did not gain him any support amongst the academic staff, even had they known about it, as he appears to have been a most insensitive individual in personal dealings. His secretary noted "he often appeared arrogant and he was in fact a strange mixture of the autocrat and the socialist." ${ }^{.90}$ Morgan's

${ }^{88}$ David Lewis, an unashamed and outspoken socialist even as a student, gives some credit for his successful Rhodes scholarship application to Beatty. Beatty chaired the Rhodes committee and deflected some of the hostility aimed at Lewis by the more conservative elements on the committee, thereby winning Lewis's "respect and gratitude." Lewis also relates that when Beatty asked what was the first thing he would do if he became the first socialist prime minister of Canada, he replied that he would nationalize the CPR. David Lewis, supra note 5 at $32-36$. Beatty articulated his own views on academic freedom in a speech at Queen's University on October 16, 1937, when he stated that there should be "freedom of thought and speech but within the limits of accurate knowledge; sound logic; a sense of responsibility, and the ordinary amenities of public life in a civilized community." This speech was published as "Freedom and the University" (Winter 1937) 44 Queen's Quarterly 463 .

${ }^{89}$ Frost, supra note 86 , vol. 2 at $195^{-96}$, cites this as being from McGill University Archives, "Chancellor Sir E. Beatty-Morgan," MG 641/276.

${ }^{90}$ Ibid. at 197 . 
relationship with Beatty appears to have been equally bad. In fact, "he succeeded in antagonizing everyone except the students: governors, professors, old and young, men and women, Englishmen, Scots, Americans, Canadians, radicals and conservatives." ${ }^{\prime 9}$ As a result of this conflict, Morgan did not last long as principal, leaving in the summer of 1937. After a second interregnum, Lewis Douglas began his term as principal in January 1938.

Douglas proved to be much more amenable to the desires of Beatty and the Board of Governors than had his predecessor. The governors, in particular, J.W. McConnell, were putting increasing pressure on the administration to do something about the apparently continuous stream of criticism of "capitalists" that was emanating from the left-wing faculty. They felt, with some justice, that they, as capitalists, were paying off the university's deficit from their own pockets and were entitled to some respect from those whose salaries they were in effect also paying..$^{92}$ Beatty communicated these feelings to Douglas, expressing the hope that Douglas could convince the more orthodox members of faculty to publicize the benefits of capitalism.

The problem facing Douglas, when he received Beatty's letter, was that moves made by the university administration to stifle leftist oratory would almost certainly result in charges of attempted suppression of academic freedom. Nor did he anticipate much success in encouraging faculty to advocate the benefits of capitalism. He therefore devised a plan aimed at strengthening the academic side of the university by only promoting a few outstanding individuals to associate professor and by letting the majority of lecturers and assistant professors go after a few years. Presumably, those individuals who were promoted would have the right sort of views. The fact that a number of prominent left-wing teachers, such as Eugene Forsey and Leonard Marsh, subsequently lost their jobs as a result of this upgrading of academic standards could be dismissed by the university administration as being purely coincidental. ${ }^{93}$ While one might have to be particularly naive to believe that the only purpose of this plan was to upgrade standards, there

${ }^{91}$ Forsey, supra note 83 at 28 .

92 Frost, supra note 86, vol. 2 at 196.

${ }^{93}$ For a more complete description of the Douglas plan and its results, see Frost, supra note 86 , vol. 2 at $200-5$. Part of the plan was a redefinition of tenurc, which was given to the rank of full and associate professor. Below the rank of associate professor, only assistant professors over forty with ten years' service, or over forty-five with five years' service, were deemed to have it. 
was little that could be done about it. Douglas, however, did not remain to implement his plan. He left for a job in American business in 1939. Cyril James, the recently appointed director of the School of Commerce, was named principal while Douglas was still on staff. The task of implementing the Douglas plan fell largely to James. A number of radical academics lost their jobs. James told Eugene Forsey that he was merely implementing a decision that had been made before he assumed office. ${ }^{94}$

The job of McConnell's particular bête noire, Frank Scott, was safe because he was already an associate professor with tenure. McConnell, owner of the Montreal Star, had to content himself with forbidding the staff of his newspaper ever to mention Scott's name in print ${ }^{95}$ Humphrey too was safe, since he had acquired tenure in September 1939 before the Douglas plan was really implemented. While the Douglas plan did not mean loss of job for any member of the Faculty of Law, it must have created an unpleasant and tense atmosphere at the university. ${ }^{96}$ This tension may have strengthened Corbett's resolve to leave, even if he was unaware of his own alleged unpopularity with the chancellor.

\section{Corbett as Candidate for Principal}

It has been suggested in various sources that Corbett should have been named principal of McGill. F.R. Scott wrote in 1979 (by which time he seems to have collapsed the decade between Currie's death and Corbett's departure into a short period of time) that "many of us at McGill hoped he would be named Principal after Sir Arthur Currie died, but the Board of Governors thought otherwise and we sadly saw him leave Canada for the United States. ${ }^{97}$ Maud Grant, warden of the Royal Victoria College (1937-40), told David Corbett that "[y] our father should have been Principal." ${ }^{18}$ Her support for Corbett is not surprising. Maud

${ }^{94}$ Frost, supra note 86 , vol. 2 at 209 , note 19 . Forsey suspected James had more to do with it than that. Forsey, supra note 83 at 28 .

${ }^{95}$ Macdonald, supra note 5 at 271.

${ }_{96}$ This was especially in the Faculty of Arts where a number of people lost their jobs. The Faculty of Law shared the same building as Arts until it was moved to Purvis Hall in $194^{2}$ in an apparent attempt to separate the dissident elements in the two faculties and to align Law with the more conservative Faculty of Commerce. Macdonald, supra note 5 at 273 , note 135 .

97 Macdonald, supra note $5^{1}$ at $13^{-1} 4$.

${ }^{98}$ Corbett, supra note 36 , "McGill," chapter 6. 
Parkin Grant was the sister of Raleigh Parkin, a long-time friend of Corbett, F.R. Scott, and Humphrey. She probably supported Corbett's candidacy during the third interregnum as she is said to have heartily disliked Cyril James. ${ }^{99}$ According to Humphrey, Corbett "should have been named principal and Canada would have retained on his native soil one of our most distinguished scholars." ${ }^{100}$ It is often suggested that one of the reasons Corbett should have received serious consideration for the position of principal was because he had helped out with the administration of the university at that level. This assistance is usually said to have taken place in the second interregnum after Morgan's resignation. Some sources say that he assumed the duties of acting principal for a year in $1938 .{ }^{101}$ Others state that when Corbett became chairman of the Senate this made him de facto acting principal. ${ }^{102}$ Humphrey said Corbett "became for a year, after the departure of Principal Morgan, the principal of the university in everything but name."103

Suggestions that Corbett was involved in the running of the university after Morgan's resignation are in fact erroneous. The only involvement Corbett had in this area was during the first interregnum. Prior to 1935, the principal was aided in his governance by "the Corporation of McGill College." 104 The corporation, which consisted of the principal, the governors, the professoriate, the fellows, and the representatives of the Graduate Society, was becoming a large and unwieldy group. Corbett was one of the leaders in the movement to reform the corporation during the first interregnum, chairing the committee to revise the University Statutes. As a result of this revision, the Senate was created on January 3o, 1935, to replace the corporation. The new Senate, with representatives

${ }^{99}$ Margaret Gillett, We Walked Very Warily: A History of Women at McGill (Montreal: Eden Press, 1981) at 192. Grant was a formidable woman not shy to voice her feelings and she "could have run the whole British Empire at the height of its power single-handed." Forsey, supra note 83 at 30 .

${ }^{100}$ J.P. Humphrey, "Thank you Percy Corbett" (September 1984) 11 Canadian Council on International Law Bulletin 5 . The full text of an earlier draft of this testimonial appears later in this article.

${ }^{101}$ Macdonald, supra note $5^{1}$ at 13 . Macdonald presumably meant 1937 and based his understanding on information received from Humphrey.

${ }^{102}$ Macdonald, supra note 5 at 265 and 271 . Although this article uses the date 1937 , it is a typographical error. Macdonald was referring to 1935 when he said Corbett was de facto acting principal.

103 Humphrey, supra note 100 at 5 .

${ }^{104}$ Frost, supra note 86, vol. 1 at 79 . 
only of the groups that had formed the corporation, had greater powers especially over academic matters. The principal would be the chairman of the Senate but, for a few months prior to the arrival of Morgan, Corbett was acting chairman. The ${ }_{1935}$ Statutes also created for the first time the position of vice-principal for Macdonald College, and the then dean of agriculture, William $\mathrm{H}$. Brittain, was selected as the first incumbent. ${ }^{105}$ It could be argued that the vice-principal, not the acting chair of the Senate, was the de facto principal. During the second interregnum in 1937, there was no doubt that this was the case. Brittain was named acting principal; however, he appears to have handled these duties from the familiar ground and relative safety of Macdonald College ${ }^{106}$ Corbett's advocacy of greater faculty involvement in the running of the university does not appear to have caused any problems with the Board of Governors. In fact, when informing the McGill community of the dramatic change from corporation to Senate he reminded his fellow advocates of university self-government of the "incalculable benefits which members of the board from time to time heaped upon McGill."107 The 1935 Statutes also stated that the Senate would be involved in the selection of future principals, although this rule did not apply to the current vacancy. Indeed, that selection process was well under way, ${ }^{108}$ and Morgan's appointment was announced two months later. Even if Corbett's role as acting chairman of the Senate had made him de facto principal, this fact could not have made him a candidate for the position of principal in 1935 since the choice had already been made. Additionally, there is no indication that Corbett was, or wanted to be, a serious candidate at this time, and every indication that he wished to back away from administrative responsibility. By the time of the second interregnum in 1937, he had nothing to do with the administration of the university and was not even a member of the Senate.

105 P.E. Corbett, "The New Statutes" (Spring 1935) 16 McGill News 39-40 and 45 .

${ }^{106}$ Dorothy McMurray, Four Principals of McGill: A Memoir 1929-I963 (Montreal: Graduates Society of McGill University, 1974) at 4o. See also Frost, supra note 86 , vol. 2 at 197 . Frost does not mention Corbett having any role, but he also covers the second interregnum in two sentences.

${ }_{107}$ Corbett, supra note 105 at 40.

${ }^{108}$ Governors W.M. Birks and W.W. Chipman had gone to England the previous fall to recruit a principal and had already selected Morgan. Eleni Bakopanos, "Arthur Eustace Morgan: The Wrong Man at the Wrong Time?" (MarchSeptember 1980) 9 McGilliana 5 . 
Despite the foregoing faulty remembrances and incorrect assertions, it is clear that a number of people expected or hoped that Corbett would be named as Morgan's successor in 1937. His experiences in helping with the administration of the university in 1935 should also have helped his candidacy. However, there is no evidence that Corbett wanted the position any more than he had done two years previously. He could not of course have advanced his own candidacy with any vigour. Of the more than sixty names submitted or suggested to the Executive Committee of the Board of Governors - and Corbett's name was probably amongst them - "not even one man proposed himself for" the position. ${ }^{109}$ By the time of the third interregnum in 1939, when friends offered to put his name forward, Corbett had firmly rejected the possibility of being considered. ${ }^{110} \mathrm{He}$ could well have rejected any similar advances in 1935 and 1937. When speculating on Corbett as a possible principal it should always be remembered that Corbett recruited Humphrey because he wished to move away from teaching and administration in order to concentrate on research.

\section{CORBETT AS "ISOLATIONIST"}

Whether Corbett was interested in the position of principal or not, it is probable that his name was proposed as a candidate at one time or another. It has been suggested that the Board of Governors failed to take his candidacy seriously because his politics were suspect. ${ }^{111}$ Specifically, it was said that he advocated neutrality - a stance that, combined with Scott's political views, had serious financial consequences for the Faculty of Law. ${ }^{112}$ Corbett did indeed find himself at the centre of a controversy over remarks he allegedly made in a radio broadcast aired over the Canadian Broadcasting Corporation's (CBC) national network on January $8,1939 .{ }^{113}$ The broadcast, entitled "Canada and War," was made with Norman MacKenzie (1894-1986), who was then a professor of international law at the University of Toronto $(1927-40)$. MacKenzie, who had started his career by succeeding Corbett as a

109 Sir Edward Beatty, "The Appointment of McGill's New Principal" (Winter 1937) 19 McGill News 7.

${ }^{110}$ Corbett, supra note 36, "McGill," chapter 6.

i: Miacdionald, supra note 5 at 271 .

112 Ibid. at 270.

${ }^{113}$ Macdonald, supra note $5^{1}$ at 30 , note 86. 
legal advisor in the International Labour Organization (ILO), was subsequently president of the University of New Brunswick (194044 ) and the University of British Columbia (1944-62), and concluded his public life in the Canadian Senate. In the broadcast, Corbett is alleged to have suggested a closer alignment with the United States, which would be likely to remain neutral in a coming war, and that Canada itself should remain neutral in any European conflict. ${ }^{114}$ It should be noted that this position seems somewhat inconsistent with his attack on CCF policy three years previously. ${ }^{115}$

An editorial in the Quebec Chronicle-Telegraph, entitled "What's the Matter with Old McGill?" commented adversely on this speech. ${ }^{116}$ The editor, Arthur Penny, ${ }^{117}$ felt that while it was not unreasonable for French-Canadians to promote neutrality and to have no feelings of loyalty towards Great Britain, it was tantamount to treason for those of British stock to advocate the same. The editor suggested that, while the authorities of the University of Toronto could be left to take care of MacKenzie, he expected McGill to take action against Corbett and thus respond to his title question with the answer, "She's all right!" 18

Beatty replied to the editor that Corbett was free to express his views but that these views should be disassociated from his university appointment. Beatty then wrote to Douglas with much the same request that he had made to Morgan four years previously:

What rather disturbs me is that those who hold opinions expressed by Professor Corbett, and as I understand is the case, Professor Scott, Mr. Forsey and other members of our staff, are accepted in the public mind as speaking for intellectual men in general ... Not as a matter of university discipline at all, but as part of the general policy of maintaining public confidence in the University, could anything be done, not to discourage Professors Corbett et al., but to persuade other officers of McGill to

${ }^{114}$ Frost, supra note 86, vol. 2 at 203.

115 Corbett, supra note 36, "Canadian Controversies: American Leanings," chapter 5. David Corbett suggests his father's views changed, among other things, because of a disappointment with British policy vis-à-vis the League of Nations and a growing belief that Canada should join the Pan American Union.

${ }^{116}$ Quebec Chronicle-Telegraph, January 9, 1939; Frost, supra note 86, vol. 2 at 203; and Corbett, supra note 36, "Canadian Controversies: American Leanings," chapter 5 , reproduces the entire editorial.

117 Arthur Guy Penny (b. 1886) was a McGill graduate (B.A. 1908) and had been editor-in-chief of the Quebec Chronicle-Telegraph since 1925 .

118 Penny was alluding to the McGill football cheer: "What's the matter with Old McGill? She's all right!" 
participate more actively than they do in the discussion of public affairs of this sort? ${ }^{119}$

It has been suggested that Beatty's reaction to Corbett's speech was "distinctly hostile" and on this basis there were negative implications for funding in the Faculty of Law and Corbett's chances for the principalship. ${ }^{120}$

There are two real difficulties with these ostensible facts. First, since neither Corbett's speech nor the administrative response to it was central to the themes of those who wrote about it, ${ }^{121}$ the matter was oversimplified and not examined in any real detail. Second, and more serious, no one, either at the time or at any subsequent time, with one exception, ${ }^{122}$ appears to have examined what Corbett actually said or even looked fully into Beatty's response. The result is that the conclusions that can be drawn from these accounts are not really fair to either Corbett or Beatty.

The editorial unleashed a storm of complaints as might be expected, and many of these complaints were directed to the chancellor. Beatty was besieged by demands for action and summary justice for Corbett from all sides - from J.W. McConnell, from societies such as the British Empire Association, and from irate parents. Somewhat shaken, Beatty took counsel with Douglas before making any public pronouncements, writing: "I do not know if there is anything which the University authorities can or should do in order to ensure wise and fitting observations by members of its staff. Corbett is an able man who periodically

119 Frost, supra note 86, vol. 2 at 205.

${ }^{120}$ Macdonald, supra note 5 at 270-71. It is clear from Macdonald's text (in note 130) that Frost's narrative formed the basis for his conclusions.

121 Frost was writing a substantial two-volume history of McGill University in which the Corbett affair was the merest sidebar. R.A. Macdonald only examined the history of the Faculty of Law to lay the groundwork for his main theme, which was the establishment of the National Law Programme in 1968, and, in any event, referred readers to Frost for a "brief review of the hostilities." Horn, supra note 86 at $117-18$, also mentioned Corbett's speech although he was more interested in the administrative response to issues of academic freedom than to what Corbett had actually said. Horn was sufficiently cautious to use the word "reportedly" when attributing remarks to Corbett, but he does not mention the final conclusion of Beatty and Douglas that Corbett had been misquoted.

122 Macdonald, supra note $5^{1}$ at $3^{0}$, note 86 , is the only authority who cites the transcript of the broadcast. It is perhaps significant that Macdonald states (in note $3^{o}$ ) that "[u]nfortunately, Frost's account does not do Corbett justice." 
indulges in theories and prophecies which might just as well not be expressed." 123 At the same time, he informed Douglas that he felt he would have to reply at least privately to Penny since the Quebec Chronicle-Telegraph was close to the Duplessis government and often spoke for it. Douglas responded urging caution and suggesting it was not in the tradition of universities, outside of those under certain dictatorships, to restrict freedom of faculty expression. It was the same kind of advice that Beatty had received from Douglas's predecessors, and he wisely followed it in his response to the editor.

A week or so after the editorial appeared, Norman MacKenzie wrote an irate letter terming the editorial "wholly inaccurate and misleading regarding myself and what I said over the C.B.C. on Sunday January eighth." 24 Apologizing, Penny acknowledged, with very little shame, that he had not actually listened to the broadcast because of his newspaper's deadline but that his conclusions had been based on the press release distributed by the $\mathrm{CBC}$ in Toronto in order to advertise the event. This press release stated what Corbett and MacKenzie would say in the most controversial but none too accurate terms, presumably to stir audience interest. Other irate readers also wrote to the editor to raise the more general concern over freedom of speech, usually with dire allusions to Germany and Italy. Penny did not apologize for his stance on suppressing neutralist views, stating that, despite his commitment to free speech, this did not extend to those individuals in the position to influence impressionable students, who should be protected by the university authorities from unacceptable views. Penny's position was not an easy one to sustain in any rational dialogue, although the entire debate was not one that was characterized by the taking of reasonable positions.

${ }^{123}$ Letter of Beatty to Douglas, January 12, 1939. McGill University Archives, "Freedom of Speech: Radicalism: Correspondence: Principal Douglas and Chancellor Beatty on Staff Speeches: 1937-1 940," Record Group oo2, File 303.

${ }^{124}$ Quebec Chronicle-Telegraph, January 19, 1939. Horn, supra note 86 at 117 , notes that MacKenzie claimed to have been misquoted in an interview, although no source is given for this information. P.B. Waite, in his biography of Mackenzie, terms the reading of the positions of both Mackenzie and Corbett as grossly distorted, referring particularly to the press coverage in the Saint John TimesGlobe, which editorialized about "two dangerous professors." See Lord of Point Grey: Larry MacKenzie of U.B.C. (Vancouver: UBC Press, 1987) at 86-87. MacKenzie protested this editorial as he had with Penny and with the same result - an apology. Waite, who termed MacKenzie and Corbett the two leading Canadian academic international lawyers between the wars $(70-71)$, for some reason lists Corbett's death date erroneously as 1955 . 
While these events were unfolding, Beatty had been undertaking a private investigation of his own on Corbett. It seems unlikely that he would have needed, or even bothered, to have made such an investigation had Corbett previously been well known as a radical. After checking with his sources, he wrote to Douglas: "In the particular case of Professor Corbett, everyone who knows him seems to esteem him, and to regard him as an authority within his own technical field. A man of that sort can be an asset to the university - even if he takes an unfortunate position on some particular question of public policy." 125

At this stage, both Beatty and Douglas appear not only to have demonstrated their prudence by not acting rashly but also to have shown a genuine understanding of the meaning of academic freedom. Their only error seems to have been that they accepted the fact that Corbett was now advocating an isolationist policy for Canada, without attempting to discover what Corbett had actually said. Douglas, whose own investigations had convinced him that "Corbett is an excellent teacher of international law," remedied this omission before he concluded the issue some months later by assuring Beatty that Corbett "has been misrepresented in the press." 127

Since most commentators omitted the step of examining what Corbett had actually said and since what he was reported to have said differed markedly from the views that he had expressed two years previously, this question is worth examining in more depth. In fact, Corbett did not simply advocate pacifism or that Canada remain neutral in the event of a war, which was basically the view expressed by F.R. Scott and the CCF. He had come to believe that, since the 1931 Statute of Westminster, Canada had the right to declare neutrality under international law. He also believed that, unless Canada declared her neutrality, any nation would be correct to assume she was automatically a belligerent in the event of Great Britain declaring war. Having reached these conclusions, Corbett advocated neutrality in the event of a British declaration of war only for as long as it would take the international community to realise that Canada was independent of Great Britain in terms of foreign affairs and that the decision to be a belligerent would be a Canadian one. He was actually advocating a decisive step towards

\footnotetext{
125 Letter of Beatty to Douglas, supra note 123, January 20, 1939.

126 Letter of Douglas to Beatty, supra note .1 23, January 12, 1939.

127 Ibid. April 27, 1939.
} 
nationhood through the severing of imperial ties. ${ }^{128}$ His position was therefore quite consistent with those he had taken previously. Since the controversial speech has been so little consulted, at the time or since, some lengthy extracts are given in this article. Corbett showed how very much aware he was that his position could be misunderstood because of media distortion:

The Canadian Broadcasting Management has asked me to state my views upon a matter in connection with which my name has been appearing in the press with a frequency which I regret almost as much as the inaccuracy of the statements attributed to me.

He continued that the question of Canadian neutrality had both political and legal aspects, and he addressed the former first:

Perhaps the bluntest and clearest way to formulate this part of the question is to ask "Should this country make clear to the world that it has the power to remain neutral, if it desires to do so, in a war involving Great Britain?"

I think it should. My reason for thinking so is that only in that way can it achieve real autonomy in foreign policy, and real autonomy in foreign policy has become highly desirable in view of the recent trend in international politics. So long as we were, or appeared to be, collaborating with Great Britain in an effort to make a success of the League of Nations, halting and reserved as that effort was, I considered the question of independent neutrality relatively unimportant. We were supporting a system which imposed the obligation not to resort to force except to stop aggression, and, if aggression occurred, to join in the sanctions designed to arrest it. Such a system, logically operated, excluded the possibility of neutrality.

That system has been abandoned. Since the Manchurian affair of 1931 , Great Britain, along with certain other members of the League, has progressively failed to fulfil the obligations of the Covenant. We ourselves are by no means free from blame for that desertion, for we played an active part in building up the network of reservations which finally reduced the League to paralysis.

In terms of the legal aspects of the questions, Corbett said that, while in his view Canada had full constitutional power to enact a law declaring neutrality, it was also evident that

[n] eutrality depends not only on ourselves, but partly also on the foreign belligerent. Historically we have been one unit with Great Britain in war, and some of our constitutionalists believe that still to be the legal position. Unless, therefore, we make a clear declaration in peacetime that our

${ }^{128}$ Macdonald, supra note $5^{1}$ at 30 , note 86. Macdonald suggests that a great deal of Canadian diplomacy in the 193 os was directed towards getting the British and the Americans to take Canada seriously as an independent nation. 
implication will depend entirely upon the decision of our Canadian authorities, a foreign belligerent could easily establish a legal case for treating us as automatically included in a declaration of war by Great Britain. Let there be no misunderstanding at this point. I do not mean a statement in peacetime that we will not go to war when Great Britain does, but simply an explicit pronouncement that we shall not be implicated in any way unless and until our own authorities in Canada announce their decision.

Corbett gave a glimpse of being both the Democrat and the soldier as he considered the value of dissent and consensus as part of the price of a free society:

I have no quarrel with people whose independent thought leads them to conclusions different from mine. All that I plead is that we shall not accept our ideas on these vital matters in ready-made, inherited patterns. I am no rebel; for if I assert the democratic right of sober but frank statement, I am content also to abide by that other rule of democracy which requires obedience to the majority when once it has declared itself. When I say this, I speak not as one who has only contemplated from an armchair the lengths to which such obedience may lead one. I speak as one who knows from intimate personal experience the ultimate requirements of citizenship. Yet, having that knowledge, I accept the rules. But I should like to discover truly what is the majority will in this question of neutrality, and that before the emotional reaction to crisis distorts our reason.

Corbett knew only too well that the storm clouds of ignorance and intolerance would gather round his head no matter how clearly he tried to express his controversial views. He presented his defence in advance and stressed the need for further dialogue, ending the speech:

One last word. This discussion has been greeted with accusations of indiscretion, even of disloyalty. The charge that there is any indiscretion or disloyalty in trying to see our way through problems that lie before our country is fantastic nonsense. Let us probe fearlessly into this question of war and peace, undeterred by the hush-hush of persons so comfortable in the status quo that they abhor all examination of possible development, all suggestion that change, even drastic change, may be desirable.

As for the allegation that Corbett advocated closer ties with the United States, that country was not even mentioned in his speech. ${ }^{129}$

129 The full text of both speeches appear in the Canadian Broadcasting Corporation's (CBC) National Forum as broadcast January 12 [i.e., January 8], 1939, over the national network of the CBC; "Canada and War" (Toronto: Canadian Broadcasting Corporation, 1939), 6. MacKenzie's text incorrectly gives the date as January 12, and this error was carried over to the title page of the publication. 
Even if the public had understood Corbett's stand on neutrality, which was a doubtful proposition at best, it was a courageous position to take in 1939. The suggestion of cutting the imperial apron strings was viewed as disloyal in many quarters and drew responses of astonishing vituperation. In the public eye, neutrality was absolute and not a temporary state within which to achieve a national status of independence. One of Beatty's correspondents argued that Corbett and his ilk should be deported to Germany or Italy since they were clearly mouthing Fascist propaganda. Corbett, perhaps too rational to understand decidedly irrational reactions, had shown with this speech as little caution in peace as he had done in war.

There are three final observations to make about Corbett's speech. First, when Great Britain did declare war in September 1939, Prime Minister Mackenzie King chose to wait a week before declaring war on Germany and that during this week the United States recognized Canada as a neutral country. Humphrey was delighted that the government followed the path recommended by Corbett, and one imagines that Corbett was also. ${ }^{130}$ Second, the notion that "Corbett's espousal of the cause of neutrality left the faculty without money or support"131 throughout the 193 os cannot be sustained since it is clear that Corbett was only thought to

One of the ironies of the suggestion that Corbett, and by extension Humphrey, were advocating closer ties with the United States is that both men were Canadian nationalists brought up in the New Brunswick Empire Loyalist tradition. When they were boys playing "war," for them the "enemy" was always the Americans. Macdonald, supra note $5^{1}$ at 31 , quotes Humphrey as advocating "at least one week's official neutrality" after a British declaration of war. In his speech, MacKenzie agreed with Corbett on all the legal points raised but felt that politically Canada should not declare neutrality because it would be a sign of weakness, and it was not something the Canadian people wanted.

${ }^{130}$ Escott Reid, who advocated neutrality throughout any conflict during the 1930s, discusses some of these problems in his autobiography Radical Mandarin: The Memoirs of Escott Reid (Toronto: University of Toronto Press, 1989) at 1 22-25. Reid states that five of seven key civil servants in the Department of External Affairs were in favour of some form of declaration of neutrality.

131 Macdonald, supra note 5 at 270 . Macdonald was attempting to understand why the Faculty of Law suffered funding losses in comparison to other faculties, notably Medicine, in the second half of the decade. While he understood Corbett's position on neutrality, he felt the general misunderstanding prevalent at the time might have had a negative impact on funding. Having read a draft of this article, he now accepts the fact that the neutrality controversy occurred too late and was of too short a duration to be the cause. One possibility, which is also speculative, is that as a dean Le Mesurier was less effective than Corbett had been at securing funding. 
espouse neutrality for a brief period at the end of the decade. If the Faculty of Law suffered more than other departments in the Depression because of administrative disapproval, the dislike of Beatty and McConnell for Scott's vociferous views must be held accountable. Third, the suggestion that Corbett's speech somehow affected his candidacy for principal must also be rejected, ${ }^{132}$ since the only time he might have been a serious candidate was in 1937 , which was over a year before the speech was made. The interpretations placed on the speech, however, may have exacerbated for Corbett the rapidly worsening climate at McGill and stirred him to leave sooner than he might have done otherwise. He might also have become weary of the frequency and perverseness with which he always șeemed to be misunderstood.

\section{Corbett And Humphrey after McGill}

After several wartime leaves of absence, Corbett departed McGill for the final time in 1944, going initially to Yale University. Humphrey, who was now isolated in his own faculty and unable to help in the war effort, ${ }^{133}$ stayed only two more years before he accepted the position as first director of the UN Division of Human Rights. Despite this separation and professional divergence, ${ }^{134}$ the two men maintained their relationship through correspondence and relatively frequent visits. Indeed, Corbett's first letter to Humphrey at the UN was dated August 2, 1946 - Humphrey's second day at the new job - and showed that the network between them would continue to operate:

This will introduce one Huntington Gilchrist, whom I first knew in Geneva 26 years ago, and whose friendship I have prized increasingly ever since. He was a senior member of the mandates section of the League, helped pilot the San Francisco Conference, and flew back and forth between London and New York finding homes for the U.N. He has done about as much solid work for international organization as any man living. You will find him grand to know, professionally and personally.

132 Macdonald, supra note 5 at 271 . It is possible of course that Corbett's unwavering advocacy of academic freedom throughout the 1930s may have drawn some negative reaction from the upper echelons at McGill.

${ }^{133}$ Humphrey offered his services to the Canadian government on several occasions. Humphrey, supra note 41 at 103-4, $111-12$.

134 Though Humphrey was now an international servant he remained an academic at heart and continued to publish. Corbett, the academic lawyer, remained committed to many of the ideals he had first espoused when he was an international servant. The Humphrey-Corbett correspondence is found in McGill University Archives $\mathrm{MG}_{4} 127$, Cont. 021 , File 418. 
Corbett's contacts with the international legal community continued to be useful to Humphrey during his UN years, but the exchange of ideas was more important as can be glimpsed in a couple of illustrations in their correspondence. Corbett's letter to Humphrey in December 1947 showed not only how closely Corbett monitored UN human rights activity but also indicated his view that the UN was not being effective at that time:

I've been reading about the doings of your various committees in Geneva, and they seemed to be winding up just in time to let people get home for Christmas. So I hope you and Jeanne are reunited in New York, or possibly even Montreal.

We arrived here on Thursday and are enjoying lovely winter weather. Night before last the lake froze over in a sheet of smooth glass. It wasn't thick enough for skating yesterday, but today we'll be out along the edges at least. We're praying the snow holds off for a day or two. David's here, and Helen and her husband and small son are coming for Christmas. ${ }^{135}$ The Mitchells are in the farmhouse, so there are the makings of many parties.

I came home from England on the "Mary" in September, and found her barbarously but comfortably luxurious. I hope you found your voyage or voyages restful. Obviously you had far too busy a life since joining the U.N. No, I've never been to Lake Success. I'm all for keeping the U.N. going, and in that direction lies, I'm sure, our main long-term hopes. But there is no denying that for the moment its business is marginal, and I have yielded to the temptation to concentrate on the big show. Actually, what has happened to me is that as I tried to pull together the fragmentary elements of world society and world law into a systematic statement, I found I had to be able to penetrate further into Soviet thought and to follow it in its possible developments. So I've spent all the time I could snatch from the affairs of a busy department in learning more about Russian language, institutions and "thought." Presently, like all obscure scholars, I hope to fuse in one synthesis all the scattered things I've done in 24 years of academic life. That is probably an illusion, but it's as happy a one as any other.

David clamors to skate. Give our love to Jeanne. Margaret says to tell you we still hope to lure you to New Haven.

Incidentally, do I really owe you a letter? I seem to remember a long and moralizing epistle about human rights to which there was no answer. But that's no matter. ${ }^{136}$

Corbett's concentration on "the big show" rather than the UN seems to refer to a study of differences between the two superpowers, the United States and the Soviet Union. He believed that the

135 Margaret Corbett's sister, daughter and best friend, Helen Penfield, all shared the same first name. In this case, Corbett is referring to his daughter.

${ }^{136}$ Humphrey-Corbett correspondence, supra note 134. 
way to peace lay through a détente between these two countries and that it was necessary to study and understand Russia in order to achieve a détente. Almost inevitably, although perhaps unconscious of the influence, Humphrey would come to the same conclusion as his mentor. A decade later, he decided to teach himself Russian, confiding to his diary: "I have also made good use of my time for I have gone through some forty pages of Hugo's Russian Grammar Simplified. I may never finish this task but learning a new language - and a difficult one - is an intellectual challenge. I also figure that if I could add one more person to the few who understand English and Russian that might add something to the conditions of international understanding."137

In 1953, after having had lunch at the UN with Percy and Margaret Corbett, Humphrey noted in his diary, "Percy has formed some opinions about the draft Covenants that come very close to mine." $138 \mathrm{He}$ followed this up two weeks later in a letter dated March 6, 1953:

I have now finished reading your excellent pamphlet on "The Individual and World Society." It is really extraordinary how working quite independently I, here, in the thick of the battle, and you, in the calm of intellectual and academic objectivity, have arrived at substantially the same conclusion concerning the United Nations human rights programme. There are, of course, some differences in our points of view but these do not diminish the importance and reality of our agreement. I think for example that I attach a good deal more importance to the Universal Declaration of Human Rights than you do. Perhaps you have underestimated its political repercussions. Indeed part of my case against the Covenants as now drafted is based on the success of the Declaration, the influence of which the Covenants now threaten to undermine. I would also have been less enthusiastic in my approval of at least the mechanics of joint ILO-ECOSOC efforts to secure compliance with generally accepted labour standards, but that is probably because I have been too closely associated with the work. I agree, of course, with the principle of cooperation and coordination, but in view of the manner in which work has been carried out in practice and the results achieved, I would not say these joint efforts constitute "the most vigorous attempt yet to secure compliance with generally accepted labour standards and declared human rights." This, however, is a long story and you could not be expected to know the details. ${ }^{139}$

${ }^{137}$ McGill University Archives, "Humphrey Diaries," MG 4127, Cont. 20, File 414, February 8, $195^{8}$.

138 Hobbins, supra note 49 , vol. 3 at 5 o.

${ }^{139}$ Humphrey-Corbett correspondence, supra note 134 . 
Humphrey tended to attach "a good deal more importance" to the Universal Declaration of Human Rights than did most people. Even before its adoption, he wrote to his sister:

The Third Committee has already adopted 17 of the 28 articles of the International Declaration of Human Rights ${ }^{140}$ so it is almost certain now that the Declaration will be adopted at this session of the General Assembly. This will be a much more important event than most people - even those who are working on it - now think. Once the Declaration has been adopted the Human Rights Commission will concentrate on the Covenant or Convention on Human Rights which will be a very different kind of thing; for it will be legally binding on the signatory States; and there will be, we hope, measures for its implementation. ${ }^{141}$

By the time of Humphrey's letter to Corbett, five years after the adoption of the declaration, the proposed convention had not been developed nor had any means of implementation been employed. To Corbett, therefore, the declaration was little more than a pious hope. To Humphrey, it had great moral authority, and he was convinced it would become part of the customary law of nations. As the years pass, Humphrey's position has been increasingly vindicated. Certainly the declaration's moral authority has caused governments to alter or repeal legislation. There are also many scholars who maintain that the declaration is part of customary international law, but this claim is too sweeping. Customary law (binding legal norms enforceable by courts) is formed by practice and not by what well-meaning scholars assert. Many, but not all, parts of the declaration have become binding in this way. Quite apart from the question of its legal effect, it is clear that the declaration is significantly affecting how nations treat their subjects, "shaming in this area being more effective than suing." 142

The relationship continued through correspondence and, whenever possible, through weekends spent together. In his diary entry for April 28, 1958, Humphrey noted: "We spent the week-end

140 The term "universal" was only formally adopted as part of the title on December 7,1948 .

${ }^{141}$ Humphrey correspondence, supra note 48 , November 11, 1948.

${ }^{142}$ I am indebted to Professor Mary Ann Glendon (first unnumbered note) who has patiently explained in several e-mails that the frequently made claim that the declaration has become part of customary international law, and therefore binding, is too broad. The explanation in the text has been distilled, hopefully accurately, from her most helpful comments many of which are paraphrased or quoted verbatim. She also recommends as further reading on the topic: Jack Goldsmith, "International Human Rights Law and the United States Double Standard" (Summer 1998) The Green Bag 365. 
with the Corbetts at Ringoes, N.J. Lots of good talk and long walks in the country. They are going to India next year for a series of lectures under the auspices of the Indian Institute of International Affairs. On Sunday Dr. and Mrs. Wilder Penfield ${ }^{143}$ came in for tea. $\mathrm{He}$ is possibly the most distinguished of living Canadians." The Corbetts and Penfields had been neighbours for many years at Magog, and Margaret Corbett and Helen Penfield were the closest of friends. The visit to India allowed Humphrey to return the favour to Corbett of giving introductions. He wrote to a number of prominent Indians of his acquaintance, including Arcot Krishnaswami, Minoo Masani, and Hansa Mehta, to introduce "a distinguished Canadian thinker and writer, who has been more recently associated with the Princeton Centre [sic] for International Studies, and who is giving a series of lectures for the Indian Institute for International Affairs in cooperation with the Ford Foundation." 144 On the same weekend, Humphrey apprised Corbett of his impending visit to South America in connection with the UN human rights seminar program. A few days later, a note in his diary showed the importance he attached to Corbett's opinions: "Had a letter today from Percy Corbett wishing me Godspeed on my South American trip. 'It's an historic job and, so far as I can see, you are going about it in the best possible way. More power to you.' This is possibly the best encouragement since I started the job 12 years ago!"145

Humphrey also tried to repay Corbett by using whatever influence he had to secure a job for Corbett's son who was "in the market for a permanent job at the United Nations." 146 He wrote to Frank Green, chief of placement services, introducing David as the

son of my very close friend professor Percy E. Corbett. Leaving aside all bias emanating from friendship and affection, I think that I can honestly say that David Corbett is one of the most brilliant and promising young intellectuals in Canada. I know you are not exactly looking for Canadians

143 Wilder Graves Penfield (1891-1976), Canadian neurologist and neurosurgeon, was the founding director of the Montreal Neurological Institute (19346o). He also taught in the Faculties of Medicine of Columbia University (192126) and McGill University (1926-54). He married Helen Kermott in 1917.

${ }^{144}$ These letters were not sent out until August 25, 1958. Humphrey-Corbett correspondence, supra note 134 .

${ }^{145}$ McGill University Archives, "Humphrey Diaries," MG 4127, Cont. O2O, File 414, May 1, $195^{8}$.

${ }^{146}$ Letter of David Corbett to John Humphrey, undated, received June 16,1958 by United Nations Record Control. Humphrey-Corbett correspondence, supra note 134 . 
but this is the kind of young man we should be recruiting whatever his nationality. ${ }^{147}$

Green replied that, although Corbett's qualifications looked excellent, he could not endorse the candidacy because there were twenty-seven member states of the UN below "their desirable range of nationals employed by the Secretariat." 148

The mandatory retirement age for international servants at the UN was sixty and as Humphrey approached that age he began to look for an academic position in which to conclude his career. He turned, as he so often had, to Corbett for advice in the matter:

I would particularly like to talk to you about my plans for the future after I leave the UN which will be in April next year. ${ }^{149}$ A number of universities have been sounding me out and there is a possibility of going to Jamaica. The longer one remains in a job, however, the more difficult it is to wrench oneself away from it and face the problems and necessary adjustments of a new life. ${ }^{150}$

Corbett suggested several people to approach at different institutions, although Humphrey eventually returned to McGill University. At this juncture, an old adversary, Principal James, had just left McGill and an old friend, Maxwell Cohen, was the new dean of law. Humphrey wrote to Corbett, still seeking advice:

I am very pleased the way things have turned out at McGill and will be returning there on or about 1 May next. It seems that I will be giving a course in international organizations to undergraduates in political science and conducting a seminar on international law for graduate students in the Law faculty. Any suggestions that you might care to send on regarding useful text books, etc. would be much appreciated. ${ }^{151}$

\section{LOSING Touch}

At some point after 1974, Corbett and Humphrey lost touch, perhaps in part because they both became widowers. ${ }^{152} \mathrm{Humphrey}$

147 Ibid., July 9, $195^{8}$.

148 Ibid., July $21,1958$.

149 Humphrey's appointment was actually extended for one year, and he did not retire until April 1966.

${ }^{150}$ Humphrey-Corbett correspondence, supra note 134 , February 28, 1964 .

151 Ibid., October 29, 1965 .

${ }^{152}$ Humphrey was remarried in 1981 to Margaret Kunstler, a medical doctor. I have not found evidence of any correspondence between Humphrey and Corbett after 1974, when Humphrey asked Corbett for advice about a course he was being asked to teach at Dalhousie Law School. 
seemed surprised in 1983 when a student, writing an independent study paper on Corbett, informed him that his mentor was still alive. That student, Kathy Fisher, told Humphrey how to get in touch with Corbett at his home in Derby Line, Vermont. Humphrey drove down that summer, and the two old friends had one last reunion full of reminiscences. Fisher states that the two "came alive, lit up, when they spoke and stepped into their old selves." 153 She was referring to Humphrey when she penned the following verse in her poem "After First Meeting Percy Corbett":

When an old friend finds a link to his mentor

older still

and sparks light up in his eyes

at the recollection

at the memories

the inspiration, aspirations, dreams

lived out

or

never to be realized. ${ }^{154}$

A few months later Corbett was dead.

\section{HuMPHREY ON CORBETT}

These relatively brief extracts from a lengthy correspondence can only give a sense of how much Corbett meant to Humphrey and how great his influence on him had been. After Corbett died, Humphrey himself tried to put this sentiment into words in a letter of condolence to Corbett's son:

It is with great sorrow that I learn about the death of your father. For he was, as you know, a close personal friend. He was also the man who introduced me to the study of international law and therefore responsible

153 E-mail from Fisher to the author (April 9, 1999). Fisher provided the information to both men that made the last meeting possible, but she was not present at the meeting. Humphrey, with Margaret Kunstler, drove down to Vermont on his own initiative, where he found Corbett with his daughter Helen. Kunstler reports that the two talked animatedly for hours about old times, pausing courteously every so often to explain matters to her.

${ }^{154}$ Kathleen E. Fisher, "After First Meeting Percy Corbett" (November 2, 1983) Quid Novi 7. Quid Novi is a student newsletter of the McGill Faculty of Law. A version of the poem, modified by Fisher, is reproduced in A Noble Roster: One Hundred and Fifty Years of Law at McGill (Montreal: McGill University Faculty of Law, 1999), 68. I am grateful to the editor, Ian Pilarczyk, for drawing it to my attention. 
for whatever career I have had here at McGill and at the United Nations. Please accept my sympathy. You can be proud to be the son of such a father. ${ }^{155}$

After the passage of several months, Humphrey wrote a far lengthier tribute, a copy of which he sent to David Corbett with the following note:

Herewith a copy of a little thing that I wrote about P.E.C. for the Canadian Council of [sic] International Law. ${ }^{156}$ I wrote it with real feeling even although they had only asked me for an obituary; but I assume it will be published. If so I will send you a copy.

I was delighted to see you and only regret that we did not have more time for talk. Be sure to let me know the next time you come to Canada. And remember also that I will be happy to help in any way that I can with that biography. ${ }^{157}$

The tribute that appears below is the text sent by Humphrey to David Corbett. There are a number of differences between this text and the published version, the more important of which are highlighted in the footnotes. It is probable that most of the changes were made by Humphrey and that he sent David Corbett an earlier version by mistake. ${ }^{158}$ Some of the changes, however, must have been made by the Bulletin editor. Humphrey would never have made the mistake of changing O.C. to Q.C. after his own name as occurred in the published version.

155 McGill University Archives, "Tributes to PEC, 1983," MG 4195, Cont. o0 1, Acc. 96 , October $27,1983$.

156 In 1991, Judge R. St. John Macdonald, in conversation with the author, suggested (possibly because that was what Humphrey then believed) that this tribute had been read by Humphrey in the McGill Senate. Macdonald felt that a comment by one outstanding legal figure on another should be published. $\mathrm{He}$ had used a copy of it for his article, supra note $5^{1}$ at 7 , note 8 , terming it an "undated three-page tribute." In fact, it was Dean J.E.C. Brierley, supra note 27 , who read the Senate resolution, and Humphrey's tribute was indeed prepared for the Canadian Council on International Law. A version of it was published in the Council's Bulletin, supra note 10o. The Bulletin is basically a mimeographed newsletter with a relatively small circulation. Humphrey's tribute was not indexed in the standard reference sources, including Index to Canadian Legal Periodicals. Under these circumstances, Judge Macdonald's suggestion that the tribute get a broader circulation seemed well worth following and provided the inspiration for this lengthier article.

157 "Tributes to PEC, 1983 ," supra note ${ }_{155}$, August 12, 1984.

${ }^{158}$ Humphrey also gave this earlier version to R. St. J. Macdonald for his article, supra note 5 . 
Thank you Percy Corbett

Percy Elwood Corbett was born on 20 December 1892 in Tyne Valley, Prince Edward Island, the son of an itinerant clergyman. When he died ninety-one years later, he had gained an international reputation as a scholar, writer and international lawyer. And although he had become an American citizen - like too many gifted Canadians - his name will probably go down in history as one of Canada's greatest legal scholars. ${ }^{159}$

It was when I was a student in the McGill Law faculty, where he was then the dean and professor of Roman and international law, that I first knew him. By that time he had already had a distinguished past. For after having himself studied at McGill he had gone to Oxford as a Rhodes scholar, had later been a fellow at All Souls College in the same university, had served in the First World War as a lieutenant in the Royal Highlanders of Canada, was wounded and awarded an M.C. and, just before taking up the deanship at McGill, had been the assistant legal advisor in the International Labour Office. Small wonder that his students, including myself, were somewhat awed by this scholar turned international official turned university dean. His course in Roman law was also the toughest in the faculty; and if you flunked in it your legal career was at an end. There was a tendency indeed to put "Pec" down as a somewhat cold intellectual. ${ }^{160}$

It was only a few years after my graduation that I really got to know the man. Although far removed from my law practice, I became interested in international law to the point that I decided to do some graduate work in the field. I talked to Dean Corbett who agreed to help me. He went so far indeed as to devote the better part of an evening every week to the gratuitous job of tutoring me. I didn't know at the time that he was planning to leave McGill and that he was looking for someone to take over his lectures in Roman law and eventually international law. ${ }^{161}$ When the university offered me a job as a junior lecturer, I accepted with alacrity. He also helped me in other ways. Amongst other things he helped me obtain a fellowship from the Carnegie Endowment for International Peace, with which he had a close relationship. This made it possible for me to study for a year at the Sorbonne in preparation for my new job. ${ }^{162}$

On my return from Paris, Percy - we were very soon in a first name relationship - and I became close friends and I learned something more about his true character which far from being coldly intellectual was essentially warm and generous. I remember with special pleasure the summer I and my late wife spent in Percy's farmhouse on Lake Memphramagog, Percy and his family having moved into a new house closer to the

159 In the Bulletin version, this sentence began: "And although, like too many gifted Canadians, he became an expatriate, his name ..." Humphrey was probably unsure whether Corbett actually became an American citizen or was merely a resident. In fact, Corbett became a naturalized American in $194^{8}$.

${ }^{160}$ In the Bulletin version, this sentence reads: "There was a tendency indeed to put "PEC" down as a somewhat difficult and cold intellectual."

161 In the Bulletin version, this sentence ends after "... his lectures."

${ }^{162}$ In the Bulletin version, this sentence reads "... study at the Sorbonne for a year ..." 
lake. ${ }^{163}$ That summer we had also driven together to Washington to attend the annual meeting of the American Society of International Law. We stopped off in New York and saw the musical comedy, "You can't take it with you." 164 People who have seen the show will remember the character whose most common remark was, "It stinks." Shortly after that trip, Percy went to Australia to attend a meeting of the Australian Institute of International Affairs. ${ }^{165}$ Jealous, because I would have dearly liked to go along, I sent him a telegram in San Francisco, where he was taking ship, with simply the words, "it stinks." 166

Percy had also somewhat changed his plans. Giving up the deanship, he decided to remain in the faculty where he would continue to teach international law; but as agreed I took over the teaching of Roman law. Not long after that however he became for a year, after the departure of Principal Morgan, the principal of the university in everything but name. He should have been named principal and Canada would have retained on his native soil one of our most distinguished scholars. But university politics dictated otherwise; and when a new principal was recruited, Percy left Canada to accept an appointment at Yale from whence he later went on to Princeton. ${ }^{167} \mathrm{He}$ was already better known in the United States as an outstanding jurist than he had been in Canada, something that may have

${ }^{163}$ In the Bulletin version, this sentence reads “... special pleasure and gratitude the summer..."

${ }^{164}$ George S. Kaufman (1889-1961), You Can't Take it With You, was first produced in December 1936.

165 Actually Corbett, along with F.R. Scott, attended the second Commonwealth Relations Conference in Sydney, Australia, in 1938. This conference was sponsored by the various Commonwealth institutes of international affairs, including the Australian institute. See H.V. Hodson, ed., The British Commonwealth and Its Future: Proceedings of the Second Unofficial Conference on British Commonwealth Relations, Sydney, 3rd-I 7 th September, 1938 (London: Oxford University Press, 1939). F.R. Scott presented the official position of the Canadian Institute of International Affairs, which was later published (see Scott, supra note 63). Corbett recalled the trip for other reasons: "As our ship was coming into harbour under the famous Sydney bridge, we were boarded by a squad of reporters. The one who got me said: 'I understand you're from McGill University. How's Stephen Leacock?" "Collard, supra note 36 at $61-62$.

${ }^{166}$ In the Bulletin version, these last two sentences are collapsed into one, reading "When shortly afterwards, Percy went to Australia to attend a meeting of the Australian Institute of International Affairs, I in my jealousy, because I would have dearly liked to go along, sent him a telegram with these same words, 'it stinks."”

${ }^{167}$ In the Bulletinversion, this sentence reads "otherwise and, after a year when an American businessman and politician was appointed to the post, Percy left Canada." Humphrey either accepted the conventional but erroneous wisdom on the question of Corbett as candidate for principal in 1937 or was possibly partially responsible for creating some of the confusion. He was studying in Europe when Morgan resigned and only returned from Europe during the last phase of the recruitment period that resulted in the hiring of Douglas. 
been a factor in his decision to expatriate himself. His reputation grew with the years as more and more books under his name were published; and at the time of his death he was universally recognized as one of the world's top international lawyers. ${ }^{168} \mathrm{He}$ was however much more than a lawyer in the sense of the practitioner. For he was also a philosopher of the law. He well understood, for example, the increasing importance of individual men and women in a changing world order where traditionally states possessed a monopoly of power and only states possessed rights or owed duties under international law. He was one of the first international lawyers to welcome the development of an international law of human rights. ${ }^{169}$ Percy Corbett was above all the kind of writer who made his readers think and who could help them generate new ideas. ${ }^{170}$ A world figure he also had appropriately a world outlook. He was a citizen of the world. ${ }^{171}$

Thank you Percy Corbett for what you did for the development of an effective international law, and thank you personally for what you did for me. ${ }^{172}$

$$
\text { John P. Humphrey, O.C. }{ }^{173}
$$

To call someone a citizen of the world was probably the highest accolade that Humphrey could bestow. One of the early titles he considered for his own autobiography ${ }^{174}$ of the UN years was Civis Mundi Sum, but ultimately he rejected it as immodest. In 1998 , Canada paid tribute to the fiftieth anniversary of the Universal Declaration of Human Rights by dedicating Festival Canada to the "Artist and Human Rights." Part of this celebration was a splendid National Arts Centre exhibit entitled: "John Humphrey: Citizen

168 In the Bulletin version, this sentence reads "... more and more books came out with his name on the covers. At the time of his death ..."

169 In the Bulletin version, this sentence reads "... the development after the Second World War of an international law ..."

170 In the Bulletin version, this sentence begins "Percy Corbett was amongst other things, the kind of writer ..."

171 In the Bulletin version, the last two sentences read "He was a world figue [sic] who appropriately also had a world outlook. His motto might well have been, civis mundi sum."

172 In the Bulletin version, this sentence reads "... Corbett for all that you did to build up an effective system of international law, and I thank you personally ..."

173 In the Bulletin version, “O.C." is wrongly changed to "Q.C." Humphrey never practiced law long enough in the 193 os to become a King's Counselor, but he was extremely proud to be named an Officer of the Order of Canada in 1974 . While entitled to put many different initials after his name, he only used O.C. for the last twenty years of his life. In a legal journal it is not, however, surprising that someone changed this to Q.C.

174 John P. Humphrey, Human Rights and the United Nations: A Creat Adventure (Dobbs Ferry, N.Y.: Transnational Publishers, 1983). Earlier drafts, including one with the title Civis Mundi Sum, are in the McGill Archives. 
of the World." Humphrey would have been proud to have been placed in Corbett's company.

ENVOI

Corbett was Humphrey's mentor in every sense of the word. He identified Humphrey's potential as a student, stimulated his interest in international law, recruited him into academe, used his contacts to ensure the vital year in France, and nurtured him through the tenure process during the turbulent years at McGill when Humphrey's political views might have cost him his job. Even when Humphrey was an established figure and director of the UN Division of Human Rights, it was Corbett's opinion that he valued most and Corbett's approval that he so earnestly desired. An interesting study could be made on the causal relationship between Corbett's ideas and Humphrey's actions. ${ }^{175}$ For example, Corbett had a great interest in international organizations, but it was Humphrey who changed the emphasis of Corbett's first-year international law course and retitled it International Law and Organization. ${ }^{176}$ Perhaps of greater significance, Corbett was one of the first legal scholars to advocate the concept of the individual in international law (which at the time only recognized nations), but it was Humphrey who put the concept into the first draft of the Universal Declaration of Human Rights. ${ }^{177}$ Thus, Humphrey was right to credit Corbett for the tremendous influence Corbett had had on his career as an academic and as an international servant, and he was equally correct to recognize the enormous contribution Corbett had made to international law scholarship in the world at large and, especially, at McGill University.

${ }^{175}$ This type of intellectual history would need to be carried out by a scholar with formal qualifications in international law.

176 Macdonald, supra note 5 at 273 .

177 Corbett's ideas were summed up in his The Individual and World Society (Princeton, NJ: 1953). 
Sommaire

Mentor et protégé: la relation entre Percy Ellwood Corbett et John Peters Humphrey

Percy Corbett et John Humphrey furent deux des personnages les plus importants dans le droit international à McGill et au Canada. L'auteur retrace les carrières de Corbett et Humphrey à McGill. Il montre l'influence qu'a eu Corbett sur Humphrey - ce dernier étant d'abord l'étudiant de Corbett non seulement à McGill, mais aussi plus tard dans la vie. L'auteur nous permet de mieux comprendre la relation entre ces deux personnages remarquables. De plus, il nous donne une idée de la façon dont le droit - et en particulier le droit international — furent enseignés à McGill durant une époque très importante de l'histoire de cette institution.

Summary

Mentor and Protégé: Percy Ellwood Corbett's Relationship with John Peters Humphrey

Percy Corbett and John Humphrey were two leading figures in international law at McGill University and in Canada. The author traces the career of Corbett and Humphrey at McGill and illustrates the influence that Corbett had on Humphrey, who had been Corbett's student, both at McGill and later in life. The author not only provides insight into the relationship of these remarkable men but also provides a picture of the teaching of law and international law at McGill University during a particularly important period of that institution. 